\title{
Estimating Price Effects in an Almost Ideal Demand Model of Outbound Thai Tourism to East Asia"
}

\author{
Chia-Lin Chang \\ Department of Applied Economics \\ Department of Finance \\ National Chung Hsing University \\ Taichung, Taiwan \\ Thanchanok Khamkaew \\ Faculty of Economics \\ Maejo University \\ Thailand \\ Michael McAleer \\ Econometric Institute \\ Erasmus School of Economics \\ Erasmus University Rotterdam \\ and \\ Tinbergen Institute \\ The Netherlands \\ and \\ Department of Quantitative Economics \\ Complutense University of Madrid \\ and \\ Department of Finance \\ National Chung Hsing University \\ Taichung, Taiwan
}

January 2012

* The authors are grateful to Ravee Phoewhawm for technical support. For financial support, the first author is grateful to the National Science Council, Taiwan, the second author thanks the Office of Higher Education Commission, Ministry of Education, Thailand, for a CHE-PhD 2550 scholarship, and the third author acknowledges the Australian Research Council, National Science Council, Taiwan, and the Japan Society for the Promotion of Science. 


\begin{abstract}
This paper analyzes the responsiveness of Thai outbound tourism to East Asian destinations, namely China, Hong Kong, Japan, Taiwan and Korea, to changes in effective relative price of tourism, total real total tourism expenditure, and one-off events. The nonlinear and linear Almost Ideal Demand (AID) models are estimated using monthly data to identify the price competitiveness and interdependencies of tourism demand for competing destinations in both long run (static) and short run error correction (dynamic) specifications. Homogeneity and symmetry are imposed in the long run and short run AID models to estimate the elasticities. The income and price elasticities provide useful information for public and private tourism agents at the various destinations to maintain and improve price competitiveness. The empirical results show that price competitiveness is important for tourism demand for Japan, Korea and Hong Kong in the long run, and for Hong Kong and Taiwan in the short run.
\end{abstract}

Keywords: Almost Ideal Demand (AID) model, tourism demand, price competitiveness, substitutes, budget shares, error correction.

JEL classifications: C3, C5, D12, L83. 


\section{Introduction}

The contribution of tourism to economic growth and development has been well documented in the literature. In recent decades, tourism has become one of the world's largest and fastest growing sectors, and has many important economic roles, especially as a major earner of foreign exchange. Numerous attempts have been made to understand the key determinants of tourism demand, with the purpose of implementing appropriate policies and strategies to attract a greater number of international visitors. As a result, competition among tourist destinations has become intense.

Price competitiveness is a major factor that could directly affect the attractiveness of a particular destination as changes in tourism prices influence the amount of tourist expenditure (Song and Witt, 2000). This indicator provides useful information that is important for developing pricing policies, planning and marketing strategies.

Although Thailand is famous for inbound tourism, the rapidly rising income levels of Thai travellers during the last decade have also fueled a quest for visiting tourism destinations abroad. Overall, $85 \%$ of Thai tourism spending takes place in the Asia-Pacific region, with most trips being of one-week duration, and to a single destination. According to the Tourism Authority of Thailand statistical reports for 1996-2007, a high proportion of outbound Thai tourists travel to East Asia, which accounts for over $80 \%$ of Thai tourists (see Figure 1).

Several countries in East Asia have adopted a tourism promotion policy for economic improvement. In this regard, there have been huge marketing and public relations activities in Thailand. Moreover, the reasons for the increasing number of outbound Thai tourists to the East Asian region are the introduction of low-cost air carriers, emerging attractive destinations, marketing strategies launched by the private and government sectors through sales promotion activities, discounts for airfares and tour programs, as well as an increasing number of flights and routes from Thai international airports to many destination cities. These factors encouraged more 
Thai tourists to travel to these destinations. Despite a sharp drop in the first and second quarters of 2003 due to the SARS outbreak in many Asian countries (see, for example, McAleer et al. (2010)), the number of outbound Thai travelers to all destinations in East Asia has increased consistently over the past few decades. The specific reduction in tourist activities was also reflected in a slowdown of outbound tourist traffic within the region, which had a negative impact on the overall Asian tourism environment. However, the reduction in Asian tourism recovered rapidly in the third and the fourth quarters of 2003 due to concerted efforts in all countries in trying to stop the spread of the disease.

In the wake of the successful "Amazing Thailand" campaign, Thailand has been able to boast some of the highest incoming tourist counts, but the lowest expenditure per traveller of any major Asian country destination. Some of this would be expected as Thailand is widely regarded as a relatively low living costs and wage rates destination. Furthermore, strategically located between destinations of great attractions of the West and the East, and between those of the Northern and Southern hemispheres, Thailand stands to gain from increased tourism in the region, especially as an attractive destination for East Asian travellers. As a member of the Association of Southeast Asian Nations (ASEAN) and the East Asia Inter-Regional Tourism Forum, Thailand is well positioned to offer packaged services and to implement joint international cooperation schemes in tourism, which should yield increased mutual benefits among countries in East Asia.

Given the special characteristics of Thai tourism, inbound tourism market is dominated by East Asian travelers, accounting for around $60 \%$ of total tourists, on average. In juxtaposition, a careful analysis of the sensitivity of outbound Thai tourism to five major destinations in East Asia is of particular interest as the empirical findings should provide useful guidance for macroeconomic policies relating to the price of the destination, inflation rates and exchange rates. East Asian provincial governments should make tourism promotion strategies, developing their own characteristics and make concerted effort instead of individual effort in order to survive in the 
competitive world tourism market. The results will also indicate the relevance to the five East Asian destinations of outbound Thai tourism, and the information necessary for the continued competitiveness and growth in East Asian. The cooperation of inter-regional tourism in East Asia will be able to complement the limits of individual regions by topological as well as cultural characteristics, thereby providing opportunities and conditions to promote tourism in the region as a whole.

Bearing these points in mind, the Almost Ideal Demand (AID) model proposed by Deaton and Muellbauer (1980a) is used to analyze outbound Thai tourism. Although the AID model has received considerable attention in the analysis of the demand for food, it can also be generalized to an aggregate level, assuming that the rational representative consumer makes multi-stage budget choices (Cortes-Jimenez et al., 2009).

The remainder of the paper is organized as follows. Section 2 presents a brief literature review. Section 3 describes the theoretical and empirical model specifications and methodology. Section 4 reports the empirical results from the nonlinear and linear AID models. Section 5 provides some concluding remarks.

\section{Literature Review}

Many empirical studies of tourism demand have relied on the single equation model (see Artus (1972), Johnson and Ashworth (1990), Sheldon (1990), Sinclair (1991) and Divisekera (1995)). These studies were based on individual country analysis, and ignored interdependencies between competing tourism destinations, which have important implications for the level of tourism demand for a given destination. In addition, these studies suffer from various theoretical and technical issues, such as the consistency with the basic axioms of utility and demand theory, the lack of an explicit and strong theoretical basis, and the absence of dynamic relationships between tourism expenditure and income or relative prices/exchange rates (Sinclair, 1998; 
Sinclair and Stabler, 1997). Consequently, attention is given in this paper to the systems approach, in which the demand for tourism to chosen destinations is modelled simultaneously.

Although there are lternative systems modelling approaches, the Almost Ideal Demand (AID) model of Deaton and Muellbauer (1980a) is very popular, and is one of the most useful frameworks to examine consumer behaviour due to its flexibility and other desirable properties. As noted in Moschini (1998), the AID model automatically satisfies the aggregation restriction and, with simple parametric restrictions, homogeneity and symmetry can be imposed to make the model internally consistent. However, the AID model may be difficult to estimate because the price index is not linear in terms of the parameters. Owing to its simplicity, the linear approximate AID model is popular for empirical studies. The AID model has been applied to model household expenditures (Blundell et al., 1994), consumption of goods (Johnson et al., 1992), and trade shares (Parikh, 1988). Several studies have also applied the AID model to analyse tourism demand.

Initially, static AID specifications focused on the choice of nonlinear and linear models and different estimation methods. Pioneering studies that modelled U.S. demand for tourism in European countries include White (1982), and O’Hagan and Harrison (1984), who analyzed the evolution of market shares of U.S. tourism expenditures in Europe from 1960-1981. White (1985) conducted a similar analysis for 1964-1981, grouping countries under seven regions and with an additional transportation equation. Sinclair and Syriopoulos (1993) investigated tourism expenditure allocations among four European origin countries. Papatheodorou (1999) studied the demand for international tourism in the Mediterranean region. Han et al. (2006) modelled U.S. tourism demand for three main European destinations. Other empirical static models include De Mello et al. (2002), Fujii, Khaled and Mark (1985), Lyssiotou (2001), and Divisekera (2003). Of these static analyses, only White (1985) and Divisekera (2003, 2009) have modelled travel and tourism demand simultaneously. 
The static (or long run) AID model implicitly assumes that there is no difference between the short and long run. Indeed, many factors such as habit persistence, imperfect information and incorrect expectation can lead to disequilibrium (see, for example, Anderson and Blundell, 1983). Thus, the assumption of a static AID model may be unrealistic. It is well known that many economic series are non-stationary, and the presence of unit roots means that the OLS t-ratios of the static AID model may be spurious (see Chambers and Nowman, 1997). As a result of the inability of the long run specification to explain dynamic adjustment of tourism demand, recent studies have focused on a dynamic framework through alternative approaches, such as cointegration and the error correction mechanism (ECM) (see Lyssiotou (2001), Durbarry and Sinclair (2003), Li et al. (2004), Mangion et al. (2005), Wu et al. (2008), and Cortés-Jiménez et al. (2009)).

There are few empirical studies of international tourism demand using econometric models for Thailand. As previous estimates from AID models in the literature have suggested that useful implications can be made regarding tourism competitiveness, the AID approach for both static and dynamic specifications will be used to investigate Thai outbound tourism demand for various destinations in East Asia.

\section{Model Specifications}

The systems approach has an advantage over the single equation approach in estimating empirical demand systems as it can analyze the interdependence of budget allocations for different consumer goods and services. Tourism decision-making involves a choice among a group of alternative destinations. The systems approach enables an analysis of the impacts of relative prices in competing destinations on tourist budget allocation so that a well-structured framework would be based on consumer demand theory. By including a group of consumer goods and estimating them simultaneously, this approach permits inferences regarding how tourists choose 
to allocate their expenditure on a number of alternative destinations. Hence, the systems approach could provide useful information about the sensitivity of tourism demand to changes in relative prices and expenditure, as well as interdependencies for competing destinations.

\subsection{Full AID Model for Tourism Demand}

The Almost Ideal Demand (AID) model of Deaton and Muellbauer (1980a, b) is one of the most widely used approaches in consumer demand analysis due to the attractive features of simplicity, theoretical consistency and relative ease of estimation. This paper estimates tourism demand within the AID framework, in which tourism demand is specified as a function of total tourist expenditures and relative prices of tourism products.

The theory of consumer behaviour is built on the three major concepts embodied in the AID model, namely the set of opportunities facing the consumer, separability and stepwise budgeting (see, for example, Durbarry and Sinclair, 2003; Han et al., 2006). The AID function in budget share form is given in Deaton and Muellbauer (1980a) as:

$$
w_{i}=\alpha_{i}+\sum_{j=1}^{n} \gamma_{i j} \log p_{j}+\beta_{i} \log \left(\frac{m}{P}\right), \quad i, j=1,2, \ldots, n
$$

where $i$ and $j$ denote specific tourist destinations, $n$ is the number of tourist destinations, $w_{i}$ is the share of tourism expenditure for destination $i, p_{j}$ is the effective relative price of tourism in destination $i, m$ is the total tourism expenditure on all destinations, $P$ is the aggregate price index, $\frac{m}{P}$ represents real total tourism expenditure, and $\alpha_{i}, \gamma_{i j}$ and $\beta_{i}$ are unknown parameters.

The aggregated price index, $P$, or the price deflator of the logarithm of total tourism expenditure (or income), in the full AID model as expressed in (1) is defined as a translog price index:

$$
\log P=\alpha_{0}+\sum_{j=1}^{n} \alpha_{j} \log p_{j}+\frac{1}{2} \sum_{j=1}^{n} \sum_{k=1}^{n} \gamma_{j k}^{*} \log p_{j} \log p_{k}
$$

The parameters $\gamma_{i j}$ are defined under (Slutsky) symmetry as follows: 


$$
\gamma_{i j}=\frac{1}{2}\left(\gamma_{i j}^{*}+\gamma_{j i}^{*}\right)=\gamma_{j i}
$$

For consistency with economic theory, three restrictions on the parameters of the AID model take the form:

$$
\begin{aligned}
& \sum_{i=1}^{n} \alpha_{i}=1, \sum_{i=1}^{n} \gamma_{i j}=0 \text { and } \sum_{i=1}^{n} \beta_{i}=0 \\
& \sum_{j=1}^{n} \gamma_{i j}=0
\end{aligned}
$$

Provided that equations (3), (4) and (5) hold, equation (1) represents a system of demand functions which add up to total expenditure $\left(\sum_{i=1}^{n} w_{i}=1\right)$, are homogeneous of degree zero in prices and total expenditure, and satisfy symmetry. The restrictions (3)-(5) are required to make the model consistent with the theory of demand. The conditions in (4) are the adding-up restrictions to ensure that $\sum_{i=1}^{n} w_{i}=1$. Homogeneity of the demand functions requires restriction (5). Slutsky symmetry is satisfied by (1) if and only if (3) holds.

Changes in the effective relative price of tourism work through the coefficient $\gamma_{i j}$ expressed in equation (1), and each $\gamma_{i j}$ represents $10^{2}$ times the effect on the $i^{\text {th }}$ share of tourism expenditure of a $1 \%$ increase in the $j^{\text {th }}$ price, with the real total tourism expenditure $\left(\frac{m}{P}\right)$ held constant. The $\beta_{i}$ coefficients represent the effect on the share of tourism expenditure allocated to destination $i$ due to the changes in real total tourism expenditure. A positive $\beta_{i}$ indicates that destination $i$ benefits from an increase in real total tourism expenditure, while a negative $\beta_{i}$ indicates an opposite effect. If a positive $\beta_{i}$ yields an expenditure elasticity value greater than unity, destination $i$ is then regarded as a luxury good. In contrast, if a positive $\beta_{i}$ yields an expenditure elasticity value between zero and one, that destination is then viewed as a necessity.

The nonlinear AID model allows straightforward derivation of the relevant elasticities due to its flexible functional form. The elasticity derivations for the AID model have been widely investigated and are well documented. For the nonlinear AID model, following Buse (1994), the expenditure elasticity, $\eta_{i}$, is given as: 


$$
\eta_{i}=1+\left(\frac{1}{w_{i}}\right)\left(\frac{\partial w_{i}}{\partial \log m}\right)=1+\left(\frac{\beta_{i}}{w_{i}}\right)
$$

The expression for the own-price $(i=j)$ elasticity is approximated by:

$$
e_{i i}=-1+\frac{\gamma_{i i}}{w_{i}}-\frac{\beta_{i}}{w_{i}}\left(\alpha_{i}+\sum_{k=1}^{n} \gamma_{k i} \log p_{k}\right)
$$

and the cross-price elasticity for $i$ and $j$ is given by:

$$
e_{i j}=\frac{\gamma_{i j}}{w_{i}}-\frac{\beta_{i}}{w_{i}}\left(\alpha_{j}+\sum_{k=1}^{n} \gamma_{k j} \log p_{k}\right)
$$

The expenditure elasticity measures the sensitivity of tourism demand for destination $i$ in response to a change in the real total tourism expenditure per tourist. The own-price and crossprice elasticities measure how a change in the effective relative price of tourism of a particular destination affects the tourism demand for itself and other competing destinations. In a similar context, Lewbel and $\mathrm{Ng}$ (2005) recommend care in the use of standard techniques for handling non-stationary regressors as a demand system that is consistent with utility maximization must be nonlinear in relative prices.

\subsection{Linear AID Model for Tourism Demand}

The only difference between the full AID model and its linear version (linear AID) lies in the specification of the price index. Several authors, including Green and Alston (1991), Pashardes (1993), Alston et al. (1994), Buse (1994), Hahn (1994), Moschini, Moro and Green (1994), Moschini (1995) and Asche and Wessels (1997), have discussed the relationship between the nonlinear and linear specifications. When prices are highly collinear, it may be adequate to approximate $P$ as proportional to some known index, $P^{*}$. Deaton and Meulbauer (1980) suggest using Stone's price index to replace the translog price index, as follows:

$$
\log P^{*}=\sum_{k=1}^{n} w_{k} \log p_{k}
$$

As Asche and Wessells (1997) observed, Stone's (1953) index is commonly used to replace the price index, $P$, for the linear AID estimation, where $w$ is the budget share among the 
destinations. The Stone index is an approximation proportional to the translog, that is, $P \cong \phi P^{*}$, where $E(\log \phi)=\alpha_{0}$. A linear AID model with the Stone index can be estimated as follows:

$$
w_{i}=\alpha_{i}^{*}+\sum_{j=1}^{n} \gamma_{i j} \log p_{j}+\beta_{i} \log \left(\frac{m}{P^{*}}\right)
$$

where $\alpha_{i}^{*}=\alpha_{i}-\beta_{i} \log \phi$. As prices are not perfectly collinear, applying the Stone index will introduce units of measurement error (see Alston, Foster and Green, 1994; Moschini, 1995).

Eales and Unnevehr (1988) showed that substitution of Stone's price index for the translog price index causes a simultaneity problem as the dependent variable $\left(w_{i t}\right)$ also appears on the right-hand side of the linear AID model. Moreover, the Stone index does not satisfy the fundamental property of index numbers because it varies with changes in the units of measurement for prices. A solution to correct the units of measurement error is to scale prices by their sample mean. As Moschini (1995) suggested, a Laspeyres price index can be used to overcome the measurement error. The Laspeyres price index is obtained by replacing $w_{k}$ in $\log P^{*}=\sum w_{k} \log p_{k}$, with $\bar{w}_{k}$ a mean share of tourism expenditure. The Laspeyres price index becomes a geometrically weighted average of prices, and is expressed as follows:

$$
\log P^{L}=\sum_{k=1}^{n} \bar{w}_{k} \log p_{k}
$$

Substitution of $\log P^{L}=\sum \bar{w}_{k} \log p_{k}$ into equation (10) yields a linear AID model with the Laspeyres price index, as follows:

$$
w_{i}=\alpha_{i}^{* *}+\sum_{j=1}^{n} \gamma_{i j} \log p_{j}+\beta_{i}\left(\log m-\sum_{k=1}^{n} \bar{w}_{k} \log p_{k}\right)
$$

where $\alpha_{i}^{* *}=\alpha_{i}-\beta_{i}\left(\alpha_{0}-\sum_{k=1}^{n} \bar{w}_{k} \log p_{k}\right)$. The linear approximate almost ideal demand, as discussed in (10) and (12), is popular in empirical studies.

Following Buse (1994) and Green and Alston (1990), the expenditure elasticity, $\eta_{i}$, is given as:

$$
\eta_{i}=1+\left(\frac{1}{w_{i}}\right)\left(\frac{\partial w_{i}}{\partial \log m}\right)=1+\left(\frac{\beta_{i}}{w_{i}}\right)
$$

and the own-price $(j=i)$ and cross-price $(j \neq i)$ elasticities are approximated by: 


$$
\begin{aligned}
& e_{i i}=-1+\left(\frac{\gamma_{i i}}{w_{i}}\right)-\beta_{i} \\
& e_{i j}=\left(\frac{\gamma_{i j}}{w_{i}}\right)-\left(\frac{\beta_{i}}{w_{i}}\right) w_{j}
\end{aligned}
$$

\subsection{Empirical Model Specifications}

\subsubsection{Dynamic specification for the AID model}

Both the nonlinear and linear empirical long run AID models are based on the model of Deaton and Muellbauer (1980a), into which seasonal dummy variables, one-off event dummy variables capturing the impacts of the SARS and Avian Influenza infections, a time trend, as well as the first and second lags of the dependent variable, may be added. The long run AID model of Thai outbound tourism demand for East Asia destinations is given as:

$$
\begin{aligned}
& w_{i t}=\alpha_{i}+\sum_{j=1}^{n} \gamma_{i j} \log p_{j t}+\beta_{i} \log \left(\frac{m}{P}\right)_{t}+\sum_{s=1}^{11} \theta_{s} D_{s t}+\phi_{1} D s+\phi_{2} D a+\psi T+ \\
& \delta_{1 i} w_{i t-1}+\delta_{2 i} w_{i t-2}+\mu_{i t}
\end{aligned}
$$

where $i$ denotes the country destination, namely China, Hong Kong, Japan, Taiwan and Korea; $j$ refers to all of the country destinations; and $t$ is time, 1998(1) to 2007(12). In the tourism context, $w_{i t}$ is the share of the tourism expenditure allocated to destination $i$ at time $t$ relative to total tourism expenditure in $j$ destinations; $\log p_{j t}$ is the logarithm of the effective relative price of tourism in destination $j$ at time $t ; m$ is the total expenditure per tourist allocated in all destinations;

$P$ is the aggregate price index; $\log \left(\frac{m}{P}\right)_{t}$ represents the logarithm of the real total tourism expenditure per tourist at time $t$; $D_{s t}$ is the seasonal dummy variables; $D s$ and $D a$ is the dummy variable capturing the impact of SARS and Avian Influenza infections, respectively; $T$ is a time trend, which can be interpreted as the annual average change in the expenditure shares; $w_{i t-1}$ and $w_{i t-2}$ are used to accommodate tourist persistence; $\mu_{i t}$ is a standard normal error term; and $\alpha_{i}, \gamma_{i j}, \beta_{i}, \theta_{s}, \phi_{1}, \phi_{2}, \psi, \delta_{1 i}$, and $\delta_{2 i}$ are unknown parameters. 
The AID model expressed above requires data on the shares of tourism expenditure, effective relative price of tourism, the aggregate price index and real total tourism expenditure per tourist. These variables, as well as the associated variables used in constructing them, are described in Table 1.

\section{[Insert Table 1 here]}

The share of total tourism expenditure allocated to each destination is a ratio of the aggregate tourism expenditure by Thai tourists in all destination countries, thereby satisfying the adding-up condition. An ideal measure of the prices of tourism products would include the prices of a basket goods and services bought by tourists at each destination, adjusted for exchange rates (see O'Hagan and Harrison (1984) and Divisekera (2009) and, in a time series context, Chang and McAleer (2010)). Salman et al. (2007) concluded that CPI is a reasonable proxy for the cost of tourism. In this paper, we use relative CPI in computing the effective relative price of tourism as an opportunity cost. The effective relative price of tourism at the destination is specified in absolute and relative terms. The effective relative prices of tourism in each country, $p_{j t}$, is given as the ratio of the CPI of the destination country $(i)$ to the country of origin $(j)$, adjusted by the relative exchange rate, to obtain a proxy for the real cost of living (Salman, 2003).

The variable $\log \left(\frac{m}{P^{*}}\right)_{i t}$ refers to the logarithm of real total tourism expenditure per tourist. The total tourism expenditure of Thai tourist in each destination is calculated from the average tourism expenditure per day, length of stay and number of outgoing Thai nationals by country of destination. Many empirical studies have used the total population of the origin country in constructing this variable. As Papatheodorou (1999) observes, dividing total tourist expenditure by total population is misleading as only travellers engage in tourism expenditure. This is likely to result in a non-stationary process for per capita expenditure. Therefore, we use the total number of Thai tourists in calculating the real total tourism expenditure per tourist. In the long run nonlinear 
AID model, the aggregate price index $(P)$ in (16) is defined as in (2). Thus, the logarithm of the real total tourism expenditure per tourist is expressed as $\log \left(\frac{m}{P}\right)_{t}, L N R E X P^{\mathrm{n}}$. In the long run linear AID model, the aggregate price index $(P)$ is approximated through the use of the Laspeyres price index, as expressed in (11). Therefore, the logarithm of the real total tourism expenditure per tourist in this case is expressed as $\log \left(\frac{m}{P^{*}}\right)_{t}, L N R E X P$.

In addition to these variables, the AID model will include a deterministic time trend $(T)$, seasonal variables, and two one-off event dummy variables. A time trend is included to detect a possible change in tourist's preferences or tastes for a particular destination. As monthly data are used for estimation, seasonal dummy variables need to be included to capture the possibly deterministic seasonal patterns of Thai outbound tourism. In addition, one-off event dummy variables are used to capture the impacts of the SARS and Avian Flu infections on Thai outbound tourism to destinations in East Asia, which were seriously affected by the spread of these outbreaks (see Kuo et al., 2009; McAleer et al., 2010). The SARS dummy variable (Ds) takes the value 1 from February 2003 to July 2003, and 0 elsewhere, while the Avian Flu dummy variable ( $D a$ ) takes the value 1 from December 2003 to July 2007, and 0 otherwise. Moreover, in line with consumer persistence, the lagged dependent variable is included in the dynamic model.

\subsubsection{Cointegration (CI) and Error Correction Mechanism (ECM)}

The long run (or static) AID model implicitly assumes that the consumer is in equilibrium. However, consumption depends on many factors, such as consumer persistence, imperfect information, adjustment costs, incorrect expectations, and misinterpreted real price changes in adjusting their expenditure instantaneously to price and income changes. If full adjustment does not occur, consumers are out of equilibrium (Anderson and Blundell, 1983). Therefore, the introduction of a short run adjustment mechanism into the long run AID model is likely to accommodate the unrealistic assumptions and statistical properties of the variables in the long run AID model. Due to lack of dynamic specification and the presence of unit roots, the asymptotic 
distribution of estimators obtained from the long run AID model may not be valid. Therefore, traditional statistics such as $t$ and $F$ may be unreliable, and OLS estimation of the long run AID model may be spurious (Granger and Newbold, 1974). In addition, the long run AID model is unlikely to generate accurate short run forecasts (Chambers, 1993; Chambers and Nowman, 1997; Li et al., 2004, 2006)

In order to overcome the problems inherent in the long run AID model, the dynamic linear AID model was developed by adopting the concepts of cointegration and ECM. Engle and Granger (1987) showed that the long run equilibrium relationship can be conveniently examined by using the cointegration (CI) technique, and the ECM describes the short run dynamic characteristics in the data. Either the Engle and Granger (1987) two-stage approach or the Johansen (1988) maximum likelihood approach can be used to test for the existence of a CI relationship among the variables. If the variables are cointegrated, an ECM of the long run relationship can be examined.

The short run AID model includes an ECM adjustment, which implies that the current change in budget shares depends not only on the current change in effective relative price of tourism and real total tourism expenditure per tourist, but also on the extent of disequilibrium in the previous period. The empirical ECM AID model follows Li et al. (2004) and Cortés-Jiménez et al. (2009), and takes the following form:

$$
\Delta w_{i t}=\alpha_{i}+\delta_{i} \Delta w_{i t-1}+\sum_{j=1}^{n} \gamma_{i j} \Delta \log p_{j t-1}+\beta_{i} \Delta \log \left(\frac{m}{P}\right)_{t-1}+\sum_{s=1}^{11} \theta_{s} D_{s t}+\phi_{1} D s+
$$

$\phi_{2} D a-\lambda_{i}\left(E C T_{i, t-1}\right)+\mu_{i t}$

where $i$ denotes the country destination, namely China, Hong Kong, Japan, Taiwan and Korea; $j$ refers to all country destinations; $t$ is time; $\Delta$ represents the first difference operator; $\Delta w_{i t}$ is the changes in value share of the tourism expenditure allocated to destination $i$ at time $t ; \Delta w_{i t-1}$ is the changes in value share of the tourism expenditure allocated to destination $i$ at time $t-1 ; \Delta \log p_{j t-1}$ is the change in the logarithm of the effective relative price of tourism in destination $j$ at time $t-1$; 
$\Delta \log \left(\frac{m}{P}\right)_{t-1}$ represent the changes in the logarithm of the real total tourism expenditure per tourist at time $t-1, \Delta L N R E X P_{t-1}^{n}$ for ECM nonlinear AID model and $\triangle L N R E X P_{t-1}$ for ECM linear AID model; $D_{s t}$ is the seasonal dummy variables; $D s$ and $D a$ are the dummy variables capturing the impact of SARS and Avian Influenza infections, respectively; and $\delta_{i}$ is a parameter of the difference of tourist budget (expenditure) share, which represents consumer tourism habits. The parameter, $\lambda_{i}$, measures the speed of adjustment towards the long run equilibrium. If $\lambda_{i}$ is close to unity, then adjustment is relatively rapid. On the other hand, if $\lambda_{i}$ is less than unity, then the adjustment towards the long run equilibrium for a destination is relatively slow.

$E C T_{i, t-1}$ is the ECM term, which measures the adjustment of the decision errors made in the previous period, and is estimated from the corresponding CI equation. Specifically, the first lag of the cointegrating vector, as obtained from Johansen's test, is included as the dynamic mechanism. The cointegrating vector is expressed as follows:

$$
E C T_{i t}=w_{i t}-\sum_{j=1}^{n} \gamma_{i j} \log p_{j t}-\beta_{i} \log \left(\frac{m}{P^{*}}\right)_{i t}-\alpha_{i}
$$

Restrictions need to be imposed on the parameters in both the unrestricted long run and ECM AID models to satisfy the theoretical properties of demand theory, namely adding-up, homogeneity and symmetry, as expressed in equations (3)-(5).

The AID models presented in equations (16) and (17) are estimated by Zellner's (1962) iterative approach for seemingly unrelated regression (ISUR). The procedure involves estimating the unrestricted model, followed by tests of the restrictions. The restricted AID model is estimated by deleting one equation from the entire system and estimating the remaining equations in accordance with the adding-up restrictions. In addition, the elasticity analysis can be easily carried out due to the flexible functional form of the AID model. The estimated coefficients of effective relative price of tourism and real total tourism expenditure resulting from the restricted long-run 
and short-run AID models are used to calculate the expenditure, own-price and cross-price elasticities, using the series of demand elasticity expressed in equations (6)-(8) and (13)-(15).

\section{Data and Empirical Results}

The AID model expressed in equations (16) and (17) requires data for the shares of tourism expenditure, effective relative price of tourism, the aggregate price index and real total tourism expenditure per tourist. Five expenditure share equations represent Thai monthly outbound tourism demand to five destinations in East Asia, namely China, Hong Kong, Japan, Taiwan and Korea, for 1998(1) to 2007(12). Tourism data used to calculate the share of total tourism expenditure and real total tourism expenditure per tourist is obtained from the statistical yearbooks of the Tourism Authority of Thailand (TAT). The data for constructing the effective relative price of tourism and the aggregate price index are obtained from the Reuter EcoWin database.

\subsection{AID Model Results}

In this section, Thai outbound tourism demand for 5 East Asia countries is examined using the long run AID models as specified in equation (16). The specification in (16) is nonlinear in the parameters due to the aggregate price index $(P)$. However, the aggregate price index is also approximately replaced with the alternative index, which is the Laspeyres price index, to obtain the linear approximation of the long run AID model. The long run nonlinear and linear AID models are estimated in order to compare the results where the aggregated price is defined differently. If the results are found to be similar, this would suggest that the linear approximation works well for Thai outbound tourism demand, and also mitigate the criticism of non-stationary processes in the nonlinear AID model (see Lewbel and $\mathrm{Ng}$ (2005)). Moreover, the first and second lags of the dependent variable are included in the nonlinear and linear models to reduce the possibility of serial correlation. 
The restrictions on the parameters are imposed on the long run AID model prior to estimation by Zellner's (1962) iterative seemingly unrelated regression (SUR) method. The parametric restrictions in the tourism demand system are tested by the Wald test. The results from the Wald tests indicate that the tourism demand models for Thailand are consistent with consumer demand theory. The long run unrestricted nonlinear and linear AID models pass all the tests for homogeneity and symmetry, and the joint test for both homogeneity and symmetry.

As homogeneity and symmetry are not rejected for the long run nonlinear and linear AID model, the restricted long run AID models are estimated to calculate the long run elasticities. In order to account for the singularity in the covariance matrix of the residuals, only $n-1$ equations are estimated by Zellner's iterative SUR method. The estimates have the same asymptotic properties as the maximum likelihood (ML) estimates, and are invariant to which the equation is omitted (Barten, 1969). The restricted estimates of the parameters in the long run nonlinear and linear AID models are reported in Tables 2-3.

\section{[Insert Tables 2-3 here]}

The own-price coefficients in most share equations are positive but insignificant, and only the own-price coefficient in Japan's budget share equation satisfies the law of the demand. The negative and significant coefficient is found in the nonlinear and linear AID models, and the extent of the impact on budget share is not very different. If Japan increases its own effective relative price by $1 \%$, the share of Thai expenditure allocated to Japan will decrease by $0.102 \%$ and $0.082 \%$, according to the long run nonlinear and linear AID models, respectively.

Consider the cross-price coefficient in China's budget share equations, where Hong Kong, Japan, and Taiwan are regarded as complementary destinations. A change in the effective relative price in Taiwan has the largest significant and negative impact on the share of Thai expenditure allocated to China in the linear AID model. A $1 \%$ increase in the effective relative price in Taiwan 
decrease China's budget share by $0.202 \%$. In accordance with symmetry, $1 \%$ increase in the effective relative price in China decreases Taiwan's budget share by $0.202 \%$. Similar evidence is found in the nonlinear AID model, but the cross-price coefficient of Taiwan's effective relative price is insignificant.

In Hong Kong's budget share equation, it is found that China and Korea are complementary destinations in the nonlinear and linear AID models. The substantial negative impact on Hong Kong's budget share is due to an increase in the effective relative price in Korea; $1 \%$ increase in the effective relative price in Korea decreases Hong Kong's budget share by $0.146 \%(0.166 \%)$ in the nonlinear (linear) AID model; and $1 \%$ increase in the effective relative price in Hong Kong decreases Korea's budget share by $0.146 \%(0.166 \%)$ in the nonlinear (linear) AID models under the symmetry restriction.

In Japan's budget share equation in both the nonlinear and linear AID models, Hong Kong and Korea are regarded as substitutes as the cross-price coefficients are positive, while China and Taiwan are complementary destinations due to their negative cross-price coefficients. The crossprice coefficient of the effective relative price of Hong Kong in the nonlinear AID model is found to be significant and positive, such that $1 \%$ increase in the effective relative price in Hong Kong increases Japan's budget share by $0.105 \%$. However, statistical insignificance is found in all the cross-price coefficients in the Japan share equation in the linear AID model.

In Taiwan's budget share equation, China and Japan are considered as complementary destinations in the nonlinear and linear AID models. The cross-price coefficient of the effective relative price in China is insignificantly negative, with a $1 \%$ increase in the effective relative price in China decreasing Taiwan's budget share by $0.115 \%$, in the nonlinear AID model. Such an impact on Taiwan's budget share is not very different from that of the linear AID model, with a $1 \%$ increase in the effective relative price in China significant decreasing Taiwan's budget share by $0.202 \%$ in the linear AID model. 
In Korea's budget share equation, only the cross-price coefficient of the Hong Kong's effective relative price is significantly negative, which indicates that Hong Kong is a complementary destination for Korea: $1 \%$ increase in the effective relative price in Hong Kong decreases Korea's budget share by $0.146 \%(0.166 \%)$ in the nonlinear (linear) AID model. In summary, Japan-Hong Kong, China-Korea, Hong Kong-Taiwan, Japan-Korea, and Taiwan-Korea are substitute destinations, while China-Hong Kong, China-Japan, China-Taiwan, Hong KongKorea and Japan-Taiwan are complementary destinations for Thai outbound tourists.

The coefficients of real total tourism expenditure per Thai outbound tourist show that Hong Kong, Taiwan and Korea benefit from an increase in real total tourism expenditure of Thai tourists, while China and Japan do not gain. Significant coefficients are found only in the China, Hong Kong and Taiwan budget share equations in the nonlinear AID model, and in the China and Korea budget share equations in the linear AID model.

The coefficients of the SARS dummy variable in all budget share equations in the nonlinear and linear AID models are significant. Japan is regarded as a safe destination. Although the coefficients of the SARS dummy variable are significant in all the budget share equations, the Avian Flu dummy variable is insignificant in all the budget share equations. The seasonal effects, trend effects, and the persistence of Thai tourism habits, can be inferred from the long run unrestricted nonlinear and linear AID models (results discussed in this section but not presented are available upon request). Regarding seasonality in the budget share equations, China and Japan are the preferred destinations for the summer and winter vacations for Thai outbound tourism, with positive and significant coefficients. Most destinations had a reduction in their budget shares during the rainy season in Thailand.

The coefficient of the trend variable can be interpreted as the annual average change in the budget share. The time trend for Hong Kong and China represents the annual increase in their shares in Thai tourism expenditure, but significance occurs only for Hong Kong in the linear AID 
model. The coefficients of the time trend for Japan, Taiwan and Korea are negative, but a temporal decrease in the budget share is found to be statistically significant only for Japan. In order to capture consumer persistence, the first and second lags of the dependent variable are included in the AID model. All share equations in the nonlinear and linear AID models support the persistence of Thai outbound tourists. The previous budget share has a positive and significant effect on the budget share in the current period for all destinations.

As the imposition of restrictions reduces the number of parameters to be estimated, both the long run restricted nonlinear and linear AID models are estimated to obtain the elasticities. For purposes of comparison, the elasticities obtained from both models are reported. As the elasticities reflect the sensitivity of demand, the implications are important for policy purposes, particularly for government and tourism-related industry policy. The expenditure and price elasticities are reported in Table 4.

\section{[Insert Table 4 here]}

For the expenditure elasticities, the values for five destinations are positive in the long run. This indicates that travel to all destinations is a normal good, and an increase in Thai total tourism expenditure increases the budget shares of all destinations. If the expenditure elasticity in a particular destination is greater than unity, travelling to such a destination would be a luxury tourism product for Thai tourists. The long run expenditure elasticities for most destinations are estimated at around 1\%, except China, which is less responsive to a change in Thai tourism expenditure. The long run expenditure elasticity of Korea is the highest to a change in total expenditure for the linear AID model. Therefore, the evidence of luxury tourism products for Thai outbound tourism in the long run are Hong Kong, Japan, Taiwan and Korea. In contrast, if a particular destination shows the expenditure elasticity to be between zero and one, then travelling 
to such a destination is a non-luxury, indicating that such a destination will benefit less than proportionately from an increase in Thai tourism expenditure.

In order to determine the price effect on tourism demand, own-price and cross-price elasticities are computed. For all five destinations, the own-price elasticities are negative. Comparing the magnitudes of the elasticities across the destinations, Japan seems to be the most sensitive to price destination in the long run, with an own-price elasticity of $-1.332(-1.398)$ in the nonlinear (linear) AID model, while Taiwan is the least price elastic, at $-0.100(-0.182)$ in the nonlinear (linear) AID model.

The cross-price elasticities are used to capture the impacts of price changes in a particular destination on the budget shares of competing destinations. Positive and negative signs for the cross-price elasticities indicate substitutability and complementarity, respectively, among the destinations. For the cross-price elasticities, the substitution effect can be found in the following pairs of destinations: China-Korea, Japan-Hong Kong, Taiwan-Hong Kong, Japan-Korea, and Taiwan-Korea. The substitutability between these pairs of destinations is associated with their culture, geographic features, and travel costs. However, the degree of substitutability between each pair of destinations is generally different, and the degree of substitutability is not symmetric. For example, a $1 \%$ increase in Korea's effective relative price leads to $0.438 \%(0.394 \%)$ increase in tourism demand for China by Thai tourists, while a $1 \%$ increase in China's effective relative price leads to $0.604 \%(0.803 \%)$ increase in tourism demand for Korea by Thai tourists, in the nonlinear (linear) model. This indicates that Korea has gained greater competitiveness relative to China in attracting Thai tourists.

The complementary effects can be observed from the same table. With regard to the crossprice elasticities, the complementary effect can be found in the following pairs of destinations: China-Hong Kong, China-Japan, China-Taiwan, Japan-Taiwan, and Korea-Hong Kong. A higher effective relative price of a particular destination leads to a lower budget share in complementary 
destinations, but the effect is not symmetric. For instance, a $1 \%$ increase in Taiwan's effective relative price leads to $0.672 \%(0.875 \%)$ decrease in tourism demand for China by Thai tourists, while a $1 \%$ increase in China's effective relative price leads to $0.770 \%(1.146 \%)$ decrease in tourism demand for Taiwan by Thai tourists in the nonlinear (linear) AID model.

The elasticities reported in Table 4 provide useful information for public and private tourism service providers in destination countries for understanding the interrelationships among the five destinations, and in adopting appropriate policies to improve their price competitiveness.

\subsection{Cointegration Test}

The analysis begins with testing for non-stationary of the variables. It is generally recognized that seasonality in tourism variables leads to distinct patterns in the series. Therefore, a test for the presence of seasonal unit roots is performed using the Franses (1991a, b) method, which extends the Hylleberg et al. (1990) (or HEGY) procedure for monthly data.

Testing for unit roots in monthly time series is equivalent to testing for the significance of the estimated coefficients in the auxiliary regression:

$$
\begin{aligned}
& \varphi^{*}(B) y_{8, t}=\pi_{1} y_{1, t-1}+\pi_{2} y_{2, t-1}+\pi_{3} y_{3, t-1}+\pi_{4} y_{3, t-2}+\pi_{5} y_{4, t-1}+\pi_{6} y_{4, t-2}+\pi_{7} y_{5, t-1}+ \\
& \pi_{8} y_{5, t-2}+\pi_{9} y_{6, t-1}+\pi_{10} y_{6, t-2}+\pi_{11} y_{7, t-1}+\pi_{12} y_{7, t-2}+\mu_{t}+\varepsilon_{t}
\end{aligned}
$$

where $\varphi^{*}(B)$ is a polynomial function of $B$, and the $y_{i, t}$, for $\mathrm{i}=1,2, \ldots, 7$, are functions of $y_{t}$ (see Hylleberg et al. (1990) for further details). Furthermore, $\mu_{t}$ in equation (19) represents the deterministic part of the model, and may consist of a constant, seasonal dummies, or deterministic trend. This depends on the alternative to the null hypothesis of 12 unit roots.

OLS estimation of equation (19) leads to estimates of $\pi_{i}$ and corresponding standard errors. Where there are seasonal unit roots, the corresponding $\pi_{i}$ are zero. As pairs of complex 
unit roots are conjugates, these roots are only present when pairs of $\pi$ 's are equal to zero simultaneously. There are no seasonal unit roots if $\pi_{2}$ through $\pi_{12}$ differ from zero. If $\pi_{1}=0$, then the presence of root 1 (at the zero frequency) is not rejected. When $\pi_{1}=0, \pi_{2}$ through $\pi_{12}$ are not equal to zero and, additionally, seasonality can be modelled with seasonal dummies, an FDSD model may emerge. In case all the $\pi_{i}=0$, for $\mathrm{i}=1,2, \ldots, 12$, the series are seasonally integrated, and it is appropriate to apply the seasonal difference filter $\left(\Delta_{12}\right)$, whereby the MSBJ model may be useful (for further details, see Franses,1991b).

The joint null hypothesis for $H_{0}: \pi_{2 \ldots . . .} \pi_{12}=0$ in all the series rejects the presence of unit roots at all seasonal frequencies at conventional levels, indicating the seasonal pattern can be represented by deterministic dummies. Results for the seasonal unit root tests on budget shares, effective relative price of tourism and real total tourism expenditure per tourist are reported in Table 5.

Furthermore, the results from the Augmented Dickey-Fuller (ADF) and Phillips-Perron (PP) unit root tests in Table 6 indicate that all the variables in the long run nonlinear and linear AID models are I(1), suggesting that the first-difference form of the AID model is appropriate. In the context of demand systems, the AID model examines the impacts of relative price effects on the value share of demand, while the differenced AID model involves the prediction of changes in value shares. However, if all the variables in the AID model are cointegrated, then the long run demand share relationship would be appropriate. The ADF test is used to test the presence of stationary residuals from the demand share equations. Figure 2 shows that the residuals from each budget share equation are stationary. These results support the use of the value share form of the AID model for long run analysis, and indicate there is a long run equilibrium relationship among the variables in the budget share equations. When the long run relationship in the AID model is detected, an ECM presentation of the AID model can be used to examine the short run dynamic relationship among the demand variables with the error correction AID model. 


\section{[Insert Tables 5-6 and Figures 1-2 here]}

\subsection{ECM Model Results}

Johansen's maximum likelihood method is used to estimate the cointegrating (CI) relationships among the variables in the dynamic (ECM) AID model. The CI vectors as obtained from CI regressions are reported in Tables 7-8. In the case of the nonlinear price index, the trace and maximum eigenvalue statistics indicate 2 cointegrating vectors in China's and Japan's shares of total expenditure equations, while only 1 cointegrating vector is detected in the remaining equations. According to the trace statistics, 1 cointegrating vector is found in the relationship among the variables, $w_{i}, L N P_{i}$ and linear price index at the $5 \%$ level in the share of tourism expenditure allocated to Hong Kong, Japan and Korea. Trace statistics and maximum eigenvalue statistics indicate 1 cointegrating vector at the 5\% level for Taiwan's share of tourism expenditure, and 2 cointegrating vectors for China's share of tourism expenditure. However, only the first cointegrating vector is used in the ECM AID model due to the primary purpose of this paper (see, for example, Cortés-Jiménez et al. (2009)).

\section{[Insert Tables 7-8 here]}

By transforming the $\mathrm{CI}$ regression into an ECM, both the long run equilibrium relationship and short run dynamics can be examined. The first lags of the selected cointegrating vectors $\left(E C T_{i, t-1}\right)$ are incorporated into equation (17) as the ECM to describe the short run dynamic characteristics. The unrestricted nonlinear and linear ECM AID models are estimated by Zellner's efficient SUR approach. The restrictions in the long run AID model are also applicable in the ECM AID model. The estimates from the nonlinear and linear ECM AID models are reported in Tables 9-10.

\section{[Insert Tables 9-10 here]}


The results from the Wald tests indicate that the unrestricted nonlinear and linear ECM models pass the homogeneity test, but do not pass the symmetry test (the results discussed in this section but not presented are available upon request). The estimates of the ECM terms are significant and negative in all differenced budget share equations, $\Delta w_{i t}$, in both the nonlinear and linear ECM AID models. These results suggest that any deviation of tourist expenditure from the long run equilibrium is adjusted dynamically, and hence the specifications of the nonlinear and linear ECM AID models are appropriate. Of the coefficients of the ECM terms, the Taiwan share equation shows the largest effect, followed by the China share equation. This implies that their speeds of adjustment to the long run equilibrium are relatively fast.

The estimates of the own-price parameters $\left(\Delta L N P_{i i}\right)$ in most differenced budget share equations, $\Delta w_{i t}$, in the linear ECM AID model are insignificant, except for Korea, which has a positive sign. The estimates of the cross-price parameters $\left(\Delta L N P_{i j}, i \neq j\right)$ are all insignificant in the nonlinear ECM AID model, but some are significant in the linear ECM AID model. For example, a change in the effective relative price in Taiwan by $1 \%$ reduces China's budget share by $0.299 \%$.

The coefficients of real total tourism expenditure per Thai outbound tourist are found to be significantly different from zero, and have a negative sign in most differenced budget share equations. This means that a change in the share of total tourism expenditure is partially reduced by the change in the share of total tourism expenditure in the previous period.

The seasonality effect can be inferred from the unrestricted nonlinear and linear ECM AID models (the unrestricted nonlinear and linear ECM model results are available upon request). The coefficient of the SARS dummy, Ds, is significant only for China and Japan, with China regarded as a risky destination during the SARS period. The coefficient of Avian Flu, $D a$, is insignificant in all differenced share equations. Concerning the role of seasonality, significant coefficients are found for April and July. As in the long run AID model, China and Japan are preferred 
destinations March-April summer vacations for Thai outbound tourism, and most destinations have a negative sign for the seasonal dummies in the rainy season from May-September.

\section{Concluding Remarks}

This paper assessed Thai outbound tourism demand for five countries in East Asia using monthly data for 1998-2007, and estimated long run and ECM AID models. The estimated parameters from the AID models provided useful information to estimate the price and expenditure elasticities, which indicate the extent to which tourism demand will change in response to effective relative price and real total tourism expenditure changes.

The results from the AID models indicated that Japan, Korea and Hong Kong were the most sensitive destinations to own price changes, while Taiwan was the most competitive destination in terms of price competitiveness. In other words, price changes have a substantial influence on tourism demand for Japan, Korea and Hong Kong, while a small impact is found for Taiwan. It appears that Korea's share benefits greatly from an increase in China's effective relative price, thereby indicating that Korea and China are substitutes for Thai tourists. Substitution effects were also found, as Hong Kong's effective relative price positively affected Japan's and Taiwan's shares of real total tourism expenditure; Japan's effective relative price positively affected Hong Kong's and Korea's shares of real total tourism expenditure; Taiwan's effective relative price positively affected Hong Kong's and Korea's shares of real total tourism expenditure; and Korea's effective relative price positively affected China's, Japan's and Taiwan's shares of real total tourism expenditure.

An increase in Hong Kong's effective relative price resulted in the largest reduction in Korea's share of real total tourism expenditure, so that Hong Kong and Korea are complements for Thai tourists. Complementary effects were also found, as China's effective relative price negatively affected Hong Kong's, Japan's and Taiwan's shares of real total tourism expenditure; 
Hong Kong's effective relative price positively affected China's and Korea's market shares; Japan's effective relative price negatively affected China's and Taiwan's market shares; Taiwan's effective relative price negatively affected China's and Japan's market shares; and Korea's effective relative price negatively affected Hong Kong’s market share.

The sensitivity of Thai outbound tourism to effective relative price changes is not particularly different for the long run nonlinear and linear AID models. The country pairs JapanHong Kong, China-Korea, Hong Kong-Taiwan, Japan-Korea and Taiwan-Korea are substitutes, while China-Hong Kong, China-Japan, China-Taiwan, Hong Kong-Korea and Japan-Taiwan are complements for Thai outbound tourism in the long run. These results indicate that pricing policy is important for competing destinations as it is crucial for maintaining price competitiveness.

Empirical analysis of the nonlinear and linear ECM AID models suggested that tourism demand for Hong Kong and Taiwan were sensitive to own-price changes. An increase in effective relative price in each destination resulted in a greater decrease in Thai tourism demand for that destination. In contrast to the long run AID specifications, Japan-Korea and Taiwan-Korea are complements as Korea's effective relative price causes decreases in Japan's and Taiwan's market shares of real total tourism expenditure. Similarly, changes in Japan's or Taiwan's effective relative prices had negative impacts on Korea's share of real total tourism expenditure.

Regarding the real total tourism expenditure elasticities, China's share of real total tourism expenditure is found to be inelastic in response to a change in real total tourism expenditure. Other destinations tended to benefit more from a change in real total tourism expenditure, as their expenditure elasticities were found to be close to or greater than unity. Korea's share of real total tourism expenditure was most sensitive to a change in expenditure in the linear AID model. The greatest impact on the share of real total tourism expenditure arose from changes in Thai tourist expenditure, which was found in Taiwan's case in the nonlinear and linear ECM AID models. 
The results from the nonlinear and linear AID models indicated that tourism demand for destinations in East Asia was sensitive to effective relative price changes, suggesting close interdependencies between these competing destinations when complements or substitutes, and expenditure (income), are changed. However, the competitiveness did not depend solely on relative tourism price level management, but also on improvements in the quality of tourism products, which have received significant consideration in the competitive world of tourism. 


\section{References}

Alston, J.M., Foster, K.A. \& Green, R.D. (1994), Estimating elasticities with the linear approximate almost ideal demand systems, Economic Letters, 71, 351-356.

Alston, J.M., Foster, K.A. \& Green, R.D. (1994), Estimating elasticities with the linear approximate almost ideal demand system: Some Monte Carlo results, Review of Economics and Statistics, 76, 351-356.

Anderson, G. \& Blundell, R. (1983), Testing restrictions in a flexible dynamic demand system: An application to consumers' expenditure in Canada, Review of Economic Studies, 50, 397-410.

Artus, J.R. (1972), An econometric analysis of international travel, IMF staff paper 19, 379-613.

Asche, F. \& Wessells, C.R. (1997), On price indices in the almost ideal demand system, American Journal of Agricultural Economics, 79, 1182-1185.

Barten, A.P. (1969), Maximum likelihood estimation: A complete system of demand equations, European Economic Review, 1, 7-73.

Blundell, R., Browning, M. \& Meghir, C. (1994), Consumer demand and life-cycle allocation of household expenditures, Review of Economic Studies, 61, 57-80.

Buse, A. (1996), Testing homogeneity in the linearized almost ideal demand system, Research paper No. 96-3, Department of Economics, University of Alberta.

Chambers, M.J. (1993), Consumer's demand in the long-run: Some evidence from UK data, Applied Economics, 25, 727-733.

Chambers, M.J. \& Nowman, K.B. (1997), Forecasting with the almost ideal demand system: Evidence from some alternative dynamic specifications, Applied Economics, 29, 935943. 
Chang, C.-L. \& McAleer, M. (2010), Aggregation, heterogeneous autoregression and volatility of daily international tourist arrivals and exchange rates. To appear in Japanese economic review. Available at SSRN: http://ssrn.com/abstract=1553377.

Cortés-Jiménez, I., Durbarry, R. \& Pulina, M. (2009), Estimation of outbound Italian tourism demand: A monthly dynamic EC-LAID model, Tourism Economics, 15, 3, 547-565.

De Mello, M.M., Pack, A. \& Sinclair, M.T. (2002), A system of equations model of UK tourism demand in neighbouring countries, Applied Economics, 34, 509-521.

Deaton, A. \& Muellbauer, J. (1980a), An almost ideal demand system, American Economic Review, 70(3), 312-326.

Deaton, A. \& Muellbauer, J. (1980b), Economics and Consumer Behavior, Cambridge, UK, Cambridge University Press.

Divisekera, S. (1995), An econometric model of international visitors flows to Australia, Australian Economic Papers, 34, 291-308.

Divisekera, S. (2003), A model of demand for international tourism, Annals of Tourism Research, $30,1-31$.

Divisekera, S. (2009), An analysis of demand for international air transportation and tourism: Interactions and dependencies, Presented at the second conference of the International Association for Tourism Economics (IATE), Chiang Mai, Thailand.

Durbarry, R. \& Sinclair, M.T. (2003), Market shares analysis: The case of French tourism demand, Annuals of Tourism Research, 30(4), 927-941.

Eales, J.S. \& Unnevehr, L.J. (1993), Simultaneity and structural change in U.S. meat demand, American Journal of Agricultural Economics, 75, 2, 259-268.

Engle, R.F. \& Granger, C.W.J. (1987), Cointegration and error correction: Representation, estimation and testing, Econometrica, 55, 251-276. 
Franses, P.H. (1991a), Model selection and seasonality in time series, Tinbergen Institute Series, No.18, The Netherlands.

Franses, P.H. (1991b), Seasonality, non-stationarity and the forecasting of monthly time series, International Journal of Forecasting, 7, 199-208.

Franses, P.H. (1997), Critical values for unit root tests in seasonal time series, Journal of Applied Statistics, 24(1), 25-47.

Fujii, E., M. Khaled \& J. Mark (1985), An almost ideal demand system for visitor expenditures, Journal of Transport Economics and Policy, 19, 161-171.

Granger, C.W.J. \& Newbold, P. (1974), Spurious regressions in econometrics, Journal of Econometrics, 2, 111-120.

Green, R. \& Alston, J.M. (1990), Elasticities in AID models, American Journal Agricultural Economics, 72, 442-445.

Green, R. \& Alston, J.M. (1991), Elasticities in AID models: A clarification and extension, American Journal Agricultural Economics, 73, 874-875.

Hahn, W. (1994), Elasticities in AID models: Comments, American Journal Agricultural Economics, 76, 972-977.

Han, Z., Durbarry, R. \& Sinclair, M.T. (2006), Modelling US tourism demand for European destinations, Tourism Management, 27(1), 1-10.

Hylleberg, S., Engle, R.F., Granger, C.W.J. \& Yoo, B.S. (1990), Seasonal integration and cointegration, Journal of Econometrics, 44(2), 215-238.

Johansen, S. (1988), A statistical analysis of cointegration vectors, Journal of Economic Dynamics and Control, 12, 231-254.

Johnson, J.A., Oksanen, E.H., Veall, M.R. \& Fretz, D. (1992), Short-run and long-run elasticities for Canadian consumption of alcoholic beverages: An error-correction mechanism/cointegration approach, Review of Economics and Statistics, 74, 64-74. 
Johnson, P. \& Ashworth, J. (1990), Modelling tourism demand: A summary review, Leisure Studies, 9, 145-160.

Kuo, H.-I., Chang, C.-L., Chen, C.-C., Huang, B.-W. \& McAleer, M. (2009), Estimating the impact of Avian Flu on international tourism demand using panel data, Tourism Economics, 15(3), 501-511.

Lewbel, A. \& Ng, S. (2005), Demand systems with nonstationary prices, Review of Economics \& Statistics, 87(3), 479-497.

Li, G., Song, H., \& Witt, S.F. (2004), Modeling tourism demand: A dynamic linear AID approach, Journal of Travel Research, 43(22), 141-150.

Li, G., Song, H., \& Witt, S.F. (2006), Time varying parameter and fixed parameter linear AID: An application to tourism demand forecasting, International Journal of Forecasting, 22, 5771.

Lyssiotou, P. (2001), Dynamic analysis of British demand for tourism abroad, Empirical Economics, 15, 421-436.

MacKinnon, J.G. (1996), Numerical distribution functions for unit root and cointegration tests, Journal of Applied Econometrics, 11, 601-618.

MacKinnon, J. G., Haug, A. A. \& Michelis, L. (1999), Numerical distribution functions of likelihood ratio tests for cointegration, Journal of Applied Econometrics, 14, 5, 563-577.

Mangion, M.L., Durbarry, R. \& Sinclair, M.T. (2005), Tourism competitiveness: Price and quality, Tourism Economics, 11(1), 45-68.

McAleer, M., Huang, B.-W., Kuo, H.-I., Chen, C.-C. \& C.-L. Chang (2010), An econometric analysis of SARS and Avian Flu on international tourist arrivals to Asia, Environmental Modelling and Software, 25, 100-106.

Moschini, G. (1995), Units of measurement and the Stone index in demand system, American Journal of Agricultural Economics, 77, 63-68. 
Moschini, G. (1998), The semiflexible almost ideal demand system, European Economics Review, $42,346-364$.

Moschini, G., D. Moro \& R.D. Green. (1994), Maintaining and testing separability in demand systems, American Journal of Agricultural Economics, 76, 61-73.

O’Hagan, J.W. \& Harrison, M.J. (1984), Market shares of US tourist expenditure in Europe: An econometric analysis, Applied Economics, 16, 919-931.

Papatheodorou, A. (1999), The demand for international tourism in the Mediterranean region, Applied Economics, 31(5), 619-630.

Parikh, A. (1988), An econometric study on estimation of trade shares using the almost ideal demand system in the world link, Applied Economics, 20, 1017- 1039.

Pashardes, P. (1993), Bias in estimating the almost ideal demand system with the stone index approximation, The Economic Journal, 103, 908-915.

Salman, A. (2003), Estimating tourist demand through cointegration analysis: Swedish data, Current Issues in Tourism, 6(4), 323-339.

Salman, A., Shukur, G. \& Von Bergmann-Winberg, M. (2007), Comparison of econometric modelling for domestic and international tourism demand: Swedish data, Current Issues in Tourism, 10(4), 323-342.

Sheldon, P.J. (1990), A review of tourism expenditure research, in C. Cooper (ed.), Progress in Tourism, Recreation and Hospitality Management, 2, London: Belhaven.

Sinclair, M.T. (1991), The economics of tourism, in C. Cooper (ed.), Progress in Tourism, Recreation and Hospitality Management, 3, London: Belhaven Press.

Sinclair, M.T. (1998), Tourism and economic development: A survey, Journal of Development Studies, 34(5), 1-51.

Sinclair, M.T. \& Stabler, M.J. (1997), The Economics of Tourism, London and New York, Routledge. 
Sinclair, M.T. \& Syriopoulos, T.C. (1993), An econometric study tourism demand: The AID model of U.S. and European tourism in Mediterranean countries, Applied Economics 25(12), 1541-1552.

Song, H. \& Witt, S.F. (2000), Tourism Demand Modeling and Forecasting: Modern Econometric Approaches, Oxford, Elsevier.

Stone, R. (1953), The measurement of consumer's expenditure and behavior in the United Kingdom 1920-1938, London, Cambridge University Press.

Thomson Reuters (2010), Reuter EcoWin Pro, Database.

Tourism Authority of Thailand (1998-2007), Annual Statistical Report on Tourism in Thailand 1998-2007, Bangkok.

White, K.J. (1982), The demand for international travel: A system-wide analysis for US travel to Western Europe, Discussion Paper No. 82/28, University of British Columbia.

White, K.J. (1985), An international travel demand model, US Travel to Western Europe, Annals of Tourism Research, 12(4), 529-545.

Wu, D., Song, H., \& Li, G. (2008), Analysis of tourist expenditure in Hong Kong using dynamic AID model, paper presented at the CAUTHE 2008 Conference, Gold Coast, Australia.

Zellner, A. (1962), An efficient method of estimating seemingly unrelated regressions and tests for aggregation bias, Journal of the American Statistical Association, 57, 348-368. 


\section{Table 1}

\section{Description of variables}

\begin{tabular}{|c|c|c|}
\hline Variables & Definition & Formulae \\
\hline$E_{i t}$ & $\begin{array}{l}\text { Tourism expenditure allocated to } \\
\text { destination } i \text { at time } t\end{array}$ & $\begin{array}{l}\qquad E_{i t}=\overline{E X}_{i t} * S T Y_{i t} * \text { tourist }_{i t} \\
\text { where } \overline{E X}_{i t} \text { is average daily tourism expenditure by Thai tourists travelling to destination } i \text { at } t \text {, STY } i t \text { is length of stay in } \\
\text { destination } i \text { at } t \text { by Thai tourists, and tourist }{ }_{i t} \text { is total number of Thai tourists travelling to destination } i \text { at } t\end{array}$ \\
\hline$T E_{t}$ & Total tourism expenditure at $t$ & $T E_{t}=\sum_{i=1}^{5} E_{i t}$ \\
\hline $\mathrm{w}_{\text {it }}$ & $\begin{array}{l}\text { Share of tourism expenditure allocated to } \\
\text { destination } i \text { at } t \text {, which refer } \\
\text { to } w_{C H t}, w_{H K t}, w_{J A P t}, w_{T W t} \text { and } w_{K O R t}\end{array}$ & $\mathrm{w}_{\mathrm{it}}=\frac{\mathrm{E}_{\mathrm{it}}}{T E_{t}}$ \\
\hline $\mathrm{m}_{\mathrm{t}}$ & Total tourism expenditure per tourist at $t$ & $\begin{array}{c}m_{t}=\frac{T E_{t}}{\text { tourist }_{t}} \\
\text { where } \text { tourist }_{t}=\text { total number of Thai tourists travelling to all five destinations at } t\end{array}$ \\
\hline $\log P_{t}$ & Logarithm of aggregate price index at $t$ & $\begin{array}{l}\text { Nonlinear aggregate price index: } \\
\qquad \begin{array}{l}\log P_{t}=\alpha_{0}+\sum_{j=1}^{n} \alpha_{j} \log p_{j t}+\frac{1}{2} \sum_{j=1}^{n} \sum_{k=1}^{n} \gamma_{j k}^{*} \log p_{j t} \log p_{k t} \\
\text { Linear aggregate price index: } \\
\log P_{t}^{L}=\sum_{k=1}^{n} \bar{w}_{k} \log p_{k t}\end{array}\end{array}$ \\
\hline $\log p_{j t}$ & $\begin{array}{l}\text { Logarithm of effective relative price index } \\
\text { of destination } j \text { at } t, \text { which refers to } \\
L N P_{C H t}, L N P_{H K t}, L N P_{J A P t}, L N P_{T W t} \text { and } \\
L N P_{K O R t}\end{array}$ & 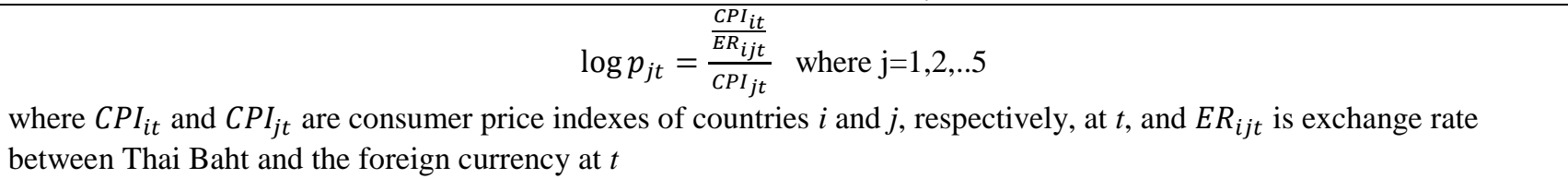 \\
\hline $\log \left(\frac{m}{P}\right)_{\mathrm{t}}$ & $\begin{array}{l}\text { Logarithm of real total tourism } \\
\text { expenditure at } t \text {, which refers to } L N R E X P^{n} \\
\text { for the nonlinear AID model and to } \\
\text { LNREXP for the linear AID model }\end{array}$ & $\log \left(\frac{m}{P}\right)_{\mathrm{t}}=\log m_{t}-\log P_{t}=\log \left(\frac{\mathrm{TE}}{\text { tourist }}\right)_{\mathrm{t}}-\log P_{t}=L N R E X P$ \\
\hline
\end{tabular}


Table 2

\section{Estimates of nonlinear AID model for Thai outbound tourism demand for East Asia}

\begin{tabular}{|c|c|c|c|c|c|}
\hline Variables & China & Hong Kong & Japan & Taiwan & Korea \\
\hline \multirow[t]{2}{*}{ Intercept } & $1.0415^{* *}$ & $-0.9822 * *$ & 0.1349 & -0.0004 & $0.8062 * * *$ \\
\hline & $(2.4419)$ & $(-2.4465)$ & $(0.4058)$ & $(-0.0013)$ & $(3.2716)$ \\
\hline \multirow{2}{*}{$\mathrm{LNP}_{\mathrm{CH}}$} & 0.0074 & -0.0739 & -0.0590 & -0.1154 & 0.0430 \\
\hline & $(0.0394)$ & $(-0.4498)$ & $(-0.9804)$ & $(-0.9680)$ & $(0.4423)$ \\
\hline \multirow[t]{2}{*}{$\mathrm{LNP}_{\mathrm{HK}}$} & -0.0739 & 0.0129 & $0.1049 *$ & 0.0438 & $-0.1460 *$ \\
\hline & $(-0.4498)$ & $(0.0776)$ & $(1.7223)$ & $(0.4185)$ & $(-1.6724)$ \\
\hline \multirow{2}{*}{$\mathrm{LNP}_{\mathrm{JAP}}$} & -0.0590 & $0.1049 *$ & $-0.0823^{*}$ & -0.0037 & 0.0014 \\
\hline & $(-0.9804)$ & $(1.7223)$ & $(-1.7429)$ & $(-0.0613)$ & $(0.0229)$ \\
\hline \multirow[t]{2}{*}{$\mathrm{LNP}_{\mathrm{TW}}$} & -0.1154 & 0.0438 & -0.0037 & 0.1836 & 0.0644 \\
\hline & $(-0.9680)$ & $(0.4185)$ & $(-0.0613)$ & $(1.3167)$ & $(0.7974)$ \\
\hline \multirow{2}{*}{$\mathrm{LNP}_{\mathrm{KOR}}$} & 0.0430 & $-0.1460 *$ & 0.0014 & 0.0644 & 0.0372 \\
\hline & $(0.4422)$ & $(-1.6724)$ & $(0.0229)$ & $(0.7974)$ & $(0.8183)$ \\
\hline \multirow[t]{2}{*}{ LNREXP $^{\mathrm{n}}$} & $-0.0788 * * *$ & $0.0550 * *$ & -0.0029 & $0.0371 *$ & 0.0104 \\
\hline & $(-3.3651)$ & $(2.4632)$ & $(-0.1459)$ & (1.8689) & $(0.7639)$ \\
\hline \multirow[t]{2}{*}{ Ds } & $-0.0861 * * *$ & -0.0273 & $0.0738 * * *$ & $-0.0459 * * *$ & \\
\hline & $(-4.4778)$ & $(-1.4300)$ & $(4.2621)$ & $(-2.8292)$ & \\
\hline \multirow[t]{2}{*}{$\mathrm{Da}$} & 0.0003 & -0.0044 & 0.0145 & $7.42 \mathrm{E}-06$ & \\
\hline & $(0.0297)$ & $(-0.3807)$ & $(1.4122)$ & $(0.0007)$ & \\
\hline \multirow{2}{*}{$w_{i t-1}$} & $0.4306 * * *$ & $0.4648 * * *$ & $0.4515 * * *$ & $0.4077 * * *$ & \\
\hline & (7.5383) & $(7.8905)$ & (7.2434) & $(6.7144)$ & \\
\hline \multirow[b]{2}{*}{$w_{i t-2}$} & 0.0429 & 0.083540 & $0.1098 *$ & -0.0362 & \\
\hline & $(0.7775)$ & $(1.4754)$ & (1.7917) & $(-0.5939)$ & \\
\hline \multirow[b]{2}{*}{$\mathrm{T}$} & 0.0007 & 0.0002 & $6.70 \mathrm{E}-06$ & -0.0006 & \\
\hline & (1.0161) & $(0.4101)$ & $(0.0203)$ & $(-1.3666)$ & \\
\hline $\mathrm{R}^{2}$ & 0.8821 & 0.8551 & 0.7562 & 0.7104 & \\
\hline Adjusted $\mathrm{R}^{2}$ & 0.8548 & 0.8215 & 0.6998 & 0.6433 & \\
\hline DW & 1.7995 & 2.1394 & 1.5062 & 2.0758 & \\
\hline
\end{tabular}

Notes: 1. Monthly dummies are controlled in the regressions.

2. t-statistics are reported in parentheses. $* * *, * *$ and $*$ indicate significance at the $1 \%, 5 \%$ and $10 \%$ levels, respectively. 
Table 3

Estimates of linear AID model for Thai outbound tourism demand for East Asia

\begin{tabular}{|c|c|c|c|c|c|}
\hline Variables & China & Hong Kong & Japan & Taiwan & Korea \\
\hline Intercept & $\begin{array}{c}1.2607 * * * \\
(2.9251)\end{array}$ & $\begin{array}{c}-0.6824 \\
(-1.6476)\end{array}$ & $\begin{array}{c}0.3732 \\
(1.1566)\end{array}$ & $\begin{array}{c}0.0625 \\
(0.1772)\end{array}$ & $\begin{array}{c}-0.0140 \\
(-0.0663)\end{array}$ \\
\hline $\mathrm{LNP}_{\mathrm{CH}}$ & $\begin{array}{c}0.1243 \\
(0.6629)\end{array}$ & $\begin{array}{c}-0.0129 \\
(-0.0783)\end{array}$ & $\begin{array}{c}-0.0006 \\
(-0.0117)\end{array}$ & $\begin{array}{l}-0.2016^{*} \\
(-1.6764)\end{array}$ & $\begin{array}{c}0.0776 \\
(0.7823)\end{array}$ \\
\hline $\mathrm{LNP}_{\mathrm{HK}}$ & $\begin{array}{c}-0.0129 \\
(-0.0783)\end{array}$ & $\begin{array}{c}0.0536 \\
(0.3136)\end{array}$ & $\begin{array}{c}0.0401 \\
(0.6700)\end{array}$ & $\begin{array}{c}0.0425 \\
(0.3980)\end{array}$ & $\begin{array}{l}-0.1655^{*} \\
(-1.8216)\end{array}$ \\
\hline $\mathrm{LNP}_{\mathrm{JAP}}$ & $\begin{array}{c}-0.0006 \\
(-0.0117)\end{array}$ & $\begin{array}{c}0.0401 \\
(0.6700)\end{array}$ & $\begin{array}{c}-0.1019 * * \\
(-2.4206)\end{array}$ & $\begin{array}{c}-0.0187 \\
(-0.3260)\end{array}$ & $\begin{array}{c}0.0402 \\
(0.6379)\end{array}$ \\
\hline $\mathrm{LNP}_{\mathrm{TW}}$ & $\begin{array}{l}-0.2016^{*} \\
(-1.6764)\end{array}$ & $\begin{array}{c}0.0425 \\
(0.3980)\end{array}$ & $\begin{array}{c}-0.0187 \\
(-0.3260)\end{array}$ & $\begin{array}{c}0.2145 \\
(1.5232)\end{array}$ & $\begin{array}{c}0.0313 \\
(0.3755)\end{array}$ \\
\hline $\mathrm{LNP}_{\mathrm{KOR}}$ & $\begin{array}{c}0.0776 \\
(0.7823)\end{array}$ & $\begin{array}{l}-0.1655^{*} \\
(-1.8216)\end{array}$ & $\begin{array}{c}0.0402 \\
(0.6379)\end{array}$ & $\begin{array}{c}0.0313 \\
(0.3755)\end{array}$ & $\begin{array}{c}0.0164 \\
(0.3828)\end{array}$ \\
\hline LNREXP & $\begin{array}{l}-0.0818 * * * \\
(-3.5999)\end{array}$ & $\begin{array}{c}0.0174 \\
(0.7698)\end{array}$ & $\begin{array}{c}-0.0082 \\
(-0.4127)\end{array}$ & $\begin{array}{c}0.0164 \\
(0.8436)\end{array}$ & $\begin{array}{l}0.0562 * * * \\
(4.8430)\end{array}$ \\
\hline Ds & $\begin{array}{l}-0.0897 * * * \\
(-4.8289)\end{array}$ & $\begin{array}{c}-0.0418 * * \\
(-2.1634)\end{array}$ & $\begin{array}{c}0.0774 * * * \\
(4.5128)\end{array}$ & $\begin{array}{l}-0.0347 * * \\
(-2.1894)\end{array}$ & \\
\hline $\mathrm{Da}$ & $\begin{array}{c}-0.0035 \\
(-0.2914)\end{array}$ & $\begin{array}{c}-0.0069 \\
(-0.5647)\end{array}$ & $\begin{array}{c}0.0161 \\
(1.5211)\end{array}$ & $\begin{array}{c}-0.0017 \\
(-0.1704)\end{array}$ & \\
\hline$w_{i t-1}$ & $\begin{array}{l}0.3827 * * * \\
(7.3310)\end{array}$ & $\begin{array}{l}0.4728 * * * \\
(8.1735)\end{array}$ & $\begin{array}{l}0.4504 * * * \\
(7.6339)\end{array}$ & $\begin{array}{l}0.4041 * * * \\
(7.0012)\end{array}$ & \\
\hline$w_{i t-2}$ & $\begin{array}{c}0.0389 \\
(0.7738)\end{array}$ & $\begin{array}{l}0.0925^{*} \\
(1.6554)\end{array}$ & $\begin{array}{c}0.0448 \\
(0.7692)\end{array}$ & $\begin{array}{c}-0.0035 \\
(-0.0597)\end{array}$ & \\
\hline $\mathrm{T}$ & $\begin{array}{c}0.0005 \\
(0.8003)\end{array}$ & $\begin{array}{c}0.0003 \\
(0.4997)\end{array}$ & $\begin{array}{c}-0.0003 \\
(-1.2282)\end{array}$ & $\begin{array}{c}-0.0003 \\
(-0.7055)\end{array}$ & \\
\hline $\mathrm{R}^{2}$ & 0.8843 & 0.8463 & 0.7562 & 0.7049 & \\
\hline Adjusted $\mathrm{R}^{2}$ & 0.8575 & 0.8107 & 0.6997 & 0.6365 & \\
\hline DW & 1.6923 & 2.1194 & 1.4836 & 2.0081 & \\
\hline
\end{tabular}

Notes: 1. Monthly dummies are controlled in the regressions.

2. t-statistics are reported in parentheses. $* * *, * *$ and $*$ indicate significance at the $1 \%, 5 \%$ and $10 \%$ levels, respectively. 
Table 4

Income and price elasticities for Thai outbound tourism to East Asia

\begin{tabular}{|c|c|c|c|c|c|c|c|}
\hline \multirow{3}{*}{ Model } & \multirow{3}{*}{ Expenditure Elasticity } & \multirow{3}{*}{ Own-price Elasticity } & \multicolumn{5}{|c|}{ Cross-price Elasticity } \\
\hline & & & \multicolumn{5}{|c|}{ Destinations } \\
\hline & & & China & $\begin{array}{l}\text { Hong } \\
\text { Kong }\end{array}$ & Japan & Taiwan & Korea \\
\hline \multicolumn{8}{|c|}{ Nonlinear AID Model } \\
\hline China & 0.631 & -0.743 & - & -0.148 & -0.228 & -0.770 & 0.604 \\
\hline Hong Kong & 1.200 & -0.752 & -0.025 & - & 0.406 & 0.036 & -1.916 \\
\hline Japan & 0.989 & -1.332 & -0.414 & 0.457 & - & -0.098 & 0.030 \\
\hline Taiwan & 1.207 & -0.100 & -0.672 & 0.088 & -0.011 & - & 0.743 \\
\hline Korea & 0.873 & -0.463 & 0.438 & -0.661 & 0.013 & 0.227 & - \\
\hline \multicolumn{8}{|c|}{ Linear AID Model } \\
\hline China & 0.617 & -0.336 & - & -0.061 & $-0.004 \quad 0.169$ & -1.146 & 0.803 \\
\hline Hong Kong & 1.063 & -0.822 & -0.045 & - & - & 0.212 & -2.216 \\
\hline Japan & 0.967 & -1.398 & -0.093 & 0.130 & -0.0690 .163 & -0.128 & 0.319 \\
\hline Taiwan & 1.092 & -0.182 & -0.875 & 0.143 & & - & 0.260 \\
\hline Korea & 1.688 & -0.855 & 0.394 & -0.608 & & 0.167 & - \\
\hline
\end{tabular}


Table 5

Seasonal unit roots tests

\begin{tabular}{|c|c|c|c|c|c|c|c|c|c|c|c|}
\hline & \multicolumn{11}{|c|}{ Auxiliary regression $^{a}$} \\
\hline & $\mathrm{w}_{\mathrm{CH}}$ & $\mathrm{w}_{\mathrm{HK}}$ & $\mathrm{w}_{\mathrm{JAP}}$ & $\mathrm{w}_{\mathrm{TW}}$ & $\mathrm{W}_{\mathrm{KOR}}$ & $\mathrm{LNP}_{\mathrm{CH}}$ & $\mathrm{LNP}_{\mathrm{HK}}$ & $\mathrm{LNP}_{\mathrm{JAP}}$ & $\mathrm{LNP}_{\mathrm{TW}}$ & $\mathrm{LNP}_{\mathrm{KOR}}$ & $L N R E X P$ \\
\hline \multicolumn{12}{|l|}{ t-statistics } \\
\hline$\pi_{1}$ & -2.470 & -1.977 & -2.329 & -2.051 & -2.783 & -1.645 & -1.574 & -1.266 & -2.893 & -2.268 & -1.906 \\
\hline$\pi_{2}$ & -0.956 & $-2.659 * *$ & $-2.603 *$ & -1.317 & -1.873 & -0.684 & -0.858 & $-2.641 *$ & $-2.570^{*}$ & $-2.499^{*}$ & $-2.501 *$ \\
\hline$\pi_{3}$ & -1.586 & -0.625 & $-1.947 *$ & -1.667 & -1.065 & $-2.128 * *$ & $-1.958^{*}$ & -0.218 & $-1.756^{*}$ & $-2.259 * *$ & -1.066 \\
\hline$\pi_{4}$ & -2.833 & -2.735 & -1.883 & -2.615 & -2.418 & -1.783 & -1.599 & $-3.709 * *$ & -1.338 & -0.802 & -1.822 \\
\hline$\pi_{5}$ & -2.691 & -2.761 & $-3.936 * *$ & -2.444 & -1.242 & -2.313 & -1.608 & -2.548 & -1.118 & -2.204 & -1.881 \\
\hline$\pi_{6}$ & -2.226 & -2.479 & $-3.76 * *$ & $-3.153 *$ & -1.681 & -2.07 & -1.222 & -2.707 & -1.726 & -2.195 & -1.830 \\
\hline$\pi_{7}$ & $2.596 *$ & $1.139 *$ & $1.351 *$ & $2.136^{*}$ & $0.755^{*}$ & $-0.665^{* *}$ & $-1.13^{* *}$ & $0.356^{*}$ & $1.175^{*}$ & $1.901 *$ & $1.958 *$ \\
\hline$\pi_{8}$ & -2.702 & -2.074 & -2.122 & -3.030 & -2.088 & -0.707 & -0.245 & -1.681 & -2.342 & $-3.176^{*}$ & -2.906 \\
\hline$\pi_{9}$ & -1.544 & -1.410 & -1.522 & -0.803 & -2.353 & -1.416 & -1.805 & -1.986 & -1.941 & -1.656 & $-2.633^{*}$ \\
\hline$\pi_{10}$ & -1.598 & -1.779 & -1.911 & -2.621 & -2.780 & -2.727 & -2.836 & -2.567 & $-3.372 * *$ & -2.749 & -1.575 \\
\hline$\pi_{11}$ & -0.607 & $-0.791 *$ & $-0.911 *$ & 0.093 & 0.292 & $-1.49 * *$ & $-1.33 * *$ & $-1.992 * *$ & -0.692 & $-1.381 * *$ & -0.317 \\
\hline$\pi_{12}$ & -1.894 & -2.282 & -1.466 & -2.649 & -2.121 & -1.772 & -1.381 & -0.482 & -1.773 & -1.641 & -2.733 \\
\hline
\end{tabular}




\begin{tabular}{|c|c|c|c|c|c|c|c|c|c|c|c|}
\hline$\pi_{3}, \pi_{4}$ & $5.601 *$ & 3.983 & 3.849 & $5.173 *$ & 3.621 & 3.751 & 3.109 & $6.998 * *$ & 2.525 & 2.946 & 2.295 \\
\hline$\pi_{5}, \pi_{6}$ & 3.621 & 3.837 & $8.049 * * *$ & $5.218 *$ & 1.518 & 2.697 & 1.339 & 3.753 & 1.819 & 2.606 & 1.861 \\
\hline$\pi_{7}, \pi_{8}$ & 3.794 & 3.332 & 2.908 & $5.359 *$ & $5.566^{*}$ & 4.065 & 3.968 & 4.278 & $4.994 *$ & $7.329 * *$ & $5.239 *$ \\
\hline$\pi_{9}, \pi_{10}$ & 1.669 & 1.767 & 2.062 & 3.629 & 4.624 & 3.726 & 4.174 & 3.702 & $5.766^{*}$ & 3.853 & 3.557 \\
\hline$\pi_{11}, \pi_{12}$ & 3.716 & $5.671 * *$ & 3.138 & $4.907 *$ & 2.7485 & $5.503^{*}$ & 3.700 & 3.589 & 3.594 & 4.765 & $6.528 * *$ \\
\hline$\pi_{2}, \ldots, \pi_{12}$ & $4.398 *$ & $6.274 * * *$ & $7.172 * * *$ & $6.069 * * *$ & $5.538 * * *$ & $5.76^{* * *}$ & $4.118 *$ & $7.513 * * *$ & $6.444 * * *$ & $7.661 * * *$ & $5.958 * * *$ \\
\hline$\pi_{1}, \ldots, \pi_{12}$ & $4.641 *$ & $6.085^{* * *}$ & $7.043 * * *$ & $5.807 * * *$ & $5.5741 * *$ & $5.544 * *$ & $4.283^{*}$ & $6.890 * * *$ & $6.661 * * *$ & $7.429 * * *$ & $5.624 * * *$ \\
\hline
\end{tabular}

Notes: ${ }^{a}$ The auxiliary regression contains constant, seasonal dummies and trend, and the number of observations is 120. $* * *, * *$ and $*$ indicate that the seasonal unit root null hypothesis is rejected at the $1 \%, 5 \%$ and $10 \%$ levels, respectively. The critical values for testing seasonal unit roots in monthly data are based on Franses (1991b, 1997). 
Table 6

\section{Unit root tests}

\begin{tabular}{|c|c|c|c|c|c|c|c|c|c|c|c|c|}
\hline \multirow{3}{*}{ Variables- } & \multicolumn{6}{|c|}{ Level } & \multicolumn{6}{|c|}{ First Difference } \\
\hline & \multicolumn{3}{|c|}{ ADF test statistics } & \multicolumn{3}{|c|}{ PP test statistic } & \multicolumn{3}{|c|}{ ADF test statistics } & \multicolumn{3}{|c|}{ PP test statistic } \\
\hline & None & Intercept & $\begin{array}{c}\text { Trend\& } \\
\text { intercept }\end{array}$ & None & tercent & tercept & None & tercent & $\begin{array}{c}\text { Trend\& } \\
\text { intercept }\end{array}$ & Tone & Intercept & $\begin{array}{c}\text { Trend\& } \\
\text { intercept }\end{array}$ \\
\hline \multirow{2}{*}{$\mathrm{w}_{\mathrm{CH}}$} & & & & & & $203 * * *$ & & & & & & On \\
\hline & $.9366)$ & 5) & ( 0.1238$)$ & & & $(0.000)$ & & & $(0.0$ & & & \\
\hline \multirow{2}{*}{$\mathrm{w}_{\mathrm{HK}}$} & -1.076 & & & & & & & & & & & \\
\hline & & 77 & $(0.2076)$ & $(0$ & & $(0.0$ & & & $(0.0$ & & & \\
\hline \multirow{2}{*}{$\mathrm{w}_{\mathrm{JAP}}$} & -0.152 & & -4.6 & & & -3.81 & & & & -16 & & \\
\hline & (2001) & $(0$, & $(0.0015)$ & $0)$ & & $(00$ & & & & & & \\
\hline \multirow{2}{*}{$\mathrm{w}_{\mathrm{TW}}$} & & $* *$ & -7.01 & & & -6.9 & & & -4.19 & -30 & -32 & -33 \\
\hline & & & $(0.0$ & & & $(0.0$ & & & & & & \\
\hline \multirow{2}{*}{$\mathrm{w}_{\mathrm{KOR}}$} & & & -6.03 & & & -6.0 & & & -10. & $* * *$ & & \\
\hline & & & $(0.00$ & & & & & & $(0.0$ & & & \\
\hline \multirow{2}{*}{$\mathrm{LNP}_{\mathrm{CH}}$} & -1.61 & -3.7 & $-3.696^{* *}$ & -1 & -3.8 & -3.9 & -10 . & *** & -10.7 & $* * *$ & -11 & -11 \\
\hline & & & $(0.0264)$ & & & $(0.0$ & & & & & & \\
\hline \multirow{2}{*}{$\mathrm{LNP}_{\mathrm{HK}}$} & $-2.409 * *$ & $-2.684 *$ & $-3.927 * *$ & $-2.333 * *$ & -2.6 & $-4.18^{* * *}$ & -10. & $3 * *$ & $-10.585^{* * *}$ & -11.1 & -11.6 & -1 \\
\hline & & & $(0.0138)$ & & & & & & & & & \\
\hline \multirow[t]{2}{*}{$\mathrm{LNP}_{\mathrm{JAP}}$} & 1.099 & & -2. & & & & -2.32 & & -3.50 & -11 & -11 & \\
\hline & & & & & & & & & & & & \\
\hline \multirow{2}{*}{$\mathrm{LNP}_{\mathrm{TW}}$} & -2 & & -2 & -2.4 & & & & & -9.8 & -10.1 & -10 & $6^{* * *}$ \\
\hline & & & & & & & & & & & & \\
\hline \multirow{2}{*}{$\mathrm{LNP}_{\mathrm{KOR}}$} & -0.493 & -1.309 & $-3.935^{* *}$ & -0.664 & -1.129 & $-3.935^{* *}$ & $-14.341 * *$ & $-14.440 *$ & $-14.464 * * *$ & $-14.873^{* * * *}$ & $-15.626^{* * *}$ & $-15.948^{* * *}$ \\
\hline & $(0.5006)$ & $0.6235)$ & $(0.0135)$ & $(0.4274)$ & & $(0.0135)$ & & & $(0.0000)$ & & & $(0.0000)$ \\
\hline \multirow[t]{2}{*}{ LNREXP } & $-2.926^{* * * *}$ & $-4.641 * *:$ & $-4.679 * *$ & $-2.701 * * *$ & $-4.679 * * *$ & $-4.739 * *:$ & $-12.243 * *$ & $-12.194 *$ & $-12.132 * * *$ & $-13.414 * * *$ & $-13.347 * * *$ & $-13.266^{* * *}$ \\
\hline & $(0.0037)$ & $(0.0002)$ & $(0.0012)$ & $(0.0072)$ & $(0.0002)$ & $(0.0010)$ & $(0.0000)$ & $(0.0000)$ & $(0.0000)$ & $(0.0000)$ & $(0.0000)$ & $(0.0000)$ \\
\hline
\end{tabular}

Notes: ***,** and * indicate that the unit root null hypothesis is rejected at the $1 \%, 5 \%$ and $10 \%$ levels, respectively.

MacKinnon (1996) one-sided p-values are given in parentheses. 
Table 7

Johansen Cointegration Analysis: Nonlinear price index

Model 1 China: $W_{C H}=f\left(\mathrm{LNP}_{\mathrm{CH}}, \mathrm{LNP}_{\mathrm{HK}}, \mathrm{LNP}_{\mathrm{JAP}}, \mathrm{LNP}_{\mathrm{TW}}, \mathrm{LNP}_{\mathrm{KOR}}, L N R E X P^{n}\right)$

\begin{tabular}{|c|c|c|c|c|c|c|}
\hline Hypothesis & $r=0$ & c.v. $\%$ & Prob.** & $r \leq 1$ & c.v.5\% & Prob.** \\
\hline Trace test & $212.0459^{*}$ & 150.5585 & 0.0000 & $125.8282^{*}$ & 117.7082 & 0.0138 \\
\hline$\lambda$ max test & $86.2177^{*}$ & 50.5999 & 0.0000 & $51.7460^{*}$ & 44.4972 & 0.0069 \\
\hline & & & & & \\
\hline
\end{tabular}

Model 2 Hong Kong: $W_{H K}=f\left(\mathrm{LNP}_{\mathrm{CH}}, \mathrm{LNP}_{\mathrm{HK}}, \mathrm{LNP}_{\mathrm{JAP}}, \mathrm{LNP}_{\mathrm{TW}}, \mathrm{LNP}_{\mathrm{KOR}}\right.$, LNREXP $\left.^{n}\right)$

\begin{tabular}{|c|c|c|c|c|c|c|}
\hline Hypothesis & $r=0$ & c.v. $5 \%$ & Prob.** & $r \leq 1$ & c.v.5\% & Prob.** \\
\hline Trace test & $162.9702^{*}$ & 150.5585 & 0.0082 & 112.1870 & 117.7082 & 0.1061 \\
\hline$\lambda$ max test & $50.7832^{*}$ & 50.5999 & 0.0478 & $44.6326^{*}$ & 44.4972 & 0.0483 \\
\hline \\
\hline
\end{tabular}

Model 3 Japan: $W_{J A P}=f\left(\mathrm{LNP}_{\mathrm{CH}}, \mathrm{LNP}_{\mathrm{HK}}, \mathrm{LNP}_{\mathrm{JAP}}, \mathrm{LNP}_{\mathrm{TW}}, \mathrm{LNP}_{\mathrm{KOR}}, L N R E X P^{n}\right)$

\begin{tabular}{|c|c|c|c|c|c|c|}
\hline Hypothesis & $r=0$ & c.v. $1 \%$ & Prob.** & $r \leq 1$ & c.v. $1 \%$ & Prob.** \\
\hline Trace test & $176.7478^{*}$ & 150.5585 & 0.0007 & $119.2061^{*}$ & 117.7082 & 0.0401 \\
\hline$\lambda$ max test & $57.5417^{*}$ & 50.5999 & 0.0083 & $48.4746 *$ & 44.4972 & 0.04175 \\
\hline \\
\hline
\end{tabular}

Model 4 Taiwan: $W_{T W}=f\left(\mathrm{LNP}_{\mathrm{CH}}, \mathrm{LNP}_{\mathrm{HK}}, \mathrm{LNP}_{\mathrm{JAP}}, \mathrm{LNP}_{\mathrm{TW}}, \mathrm{LNP}_{\mathrm{KOR}}, L N R E X P^{n}\right)$

\begin{tabular}{|c|c|c|c|c|c|c|}
\hline Hypothesis & $r=0$ & $c . v .5 \%$ & Prob.** & $r \leq 1$ & c.v. $5 \%$ & Prob.** \\
\hline Trace test & $175.7375^{*}$ & 125.6154 & 0.0000 & 92.1441 & 95.7537 & 0.0863 \\
\hline$\lambda$ max test & $83.2934^{*}$ & 46.2314 & 0.0000 & 37.2774 & 40.0776 & 0.1000 \\
\hline & & & & \\
\hline \\
ECT $=W_{T W}+0.6326 \mathrm{LNP}_{\mathrm{CH}}+0.1775 \mathrm{LNP}_{\mathrm{HK}}+0.1932 \mathrm{LNP}_{\mathrm{JAP}}-0.0086 \mathrm{LNP}_{\mathrm{TW}}-0.8647 \mathrm{LNP}_{\mathrm{KOR}}-0.0246 L N R E X P^{n}-0.0744$ \\
\\
$(0.0689)$ & $(0.0805)$ & $(0.0808)$ & $(0.1157)$ & $(0.1745)$ & $(0.0206)$ \\
\end{tabular}

Model 5 Korea: $W_{K O R}=f\left(\mathrm{LNP}_{\mathrm{CH}}, \mathrm{LNP}_{\mathrm{HK}}, \mathrm{LNP}_{\mathrm{JAP}}, \mathrm{LNP}_{\mathrm{TW}}, \mathrm{LNP}_{\mathrm{KOR}}, L N R E X P^{n}\right)$

\begin{tabular}{|c|c|c|c|c|c|c|}
\hline Hypothesis & $r=0$ & c.v. $5 \%$ & Prob.** & $r \leq 1$ & c.v.5\% & Prob.** \\
\hline Trace test & $131.0677 *$ & 125.6154 & 0.0223 & 87.4700 & 95.7537 & 0.1620 \\
\hline$\lambda$ max test & 43.5977 & 46.2314 & 0.0934 & 33.8924 & 40.0776 & 0.2106 \\
\hline \\
\hline
\end{tabular}

Note: $(1) *$ denotes rejection of the null hypothesis at the 5\% level, ** MacKinnon-Haug-Michelis (1999) p-values. (2) standard error in parentheses. (3) Cointegrating vector lags were chosen on the basis of AIC, HQ and SC criteria. (4) c.v. denotes critical value. 


\section{Table 8}

\section{Johansen Cointegration Analysis: Linear price index}

Model 1 China: $W_{C H}=f\left(\mathrm{LNP}_{\mathrm{CH}}, \mathrm{LNP}_{\mathrm{HK}}, \mathrm{LNP}_{\mathrm{JAP}}, \mathrm{LNP}_{\mathrm{TW}}, \mathrm{LNP}_{\mathrm{KOR}}, L N R E X P\right)$

\begin{tabular}{|c|c|c|c|c|c|c|}
\hline Hypothesis & $r=0$ & c.v. $5 \%$ & Prob.** & $r \leq 1$ & c.v.5\% & Prob.** \\
\hline Trace test & $178.257^{*}$ & 150.5585 & 0.0005 & $173.945^{*}$ & 117.708 & 0.0293 \\
\hline$\lambda$ max test & $57.0179^{*}$ & 50.5998 & 0.0095 & $45.3713^{*}$ & 44.4972 & 0.0401 \\
\hline
\end{tabular}

$\mathrm{ECT}=W_{C H}+0.4751 \mathrm{LNP}_{\mathrm{CH}}-0.0586 \mathrm{LNP}_{\mathrm{HK}}-0.3137 \mathrm{LNP}_{\mathrm{JAP}}+0.6843 \mathrm{LNP}_{\mathrm{TW}}+0.1464 \mathrm{LNP}_{\mathrm{KOR}}+0.0479 \mathrm{LNREXP}-0.0048$ Trend -0.6852
$(0.4225)$
$(0.1657)$
(0.2198)
$(0.4243)$
(0.966)
$(0.3366)$
$(0.0420)$

Model 2 Hong Kong: $W_{H K}=f\left(\mathrm{LNP}_{\mathrm{CH}}, \mathrm{LNP}_{\mathrm{HK}}, \mathrm{LNP}_{\mathrm{JAP}}, \mathrm{LNP}_{\mathrm{TW}}, \mathrm{LNP}_{\mathrm{KOR}}\right.$, LNREXP $)$

\begin{tabular}{|c|c|c|c|c|c|c|}
\hline Hypothesis & $r=0$ & c.v.5\% & Prob.*** & $r \leq 1$ & c.v.5\% & Prob.*** \\
\hline Trace test & $157.7672^{*}$ & 150.5585 & 0.0183 & 111.7392 & 117.7082 & 0.1123 \\
\hline$\lambda$ max test & 46.0279 & 50.5998 & 0.1383 & 43.4667 & 44.4972 & 0.0644 \\
\hline
\end{tabular}

$\mathrm{ECT}=W_{H K}+2.9885 \mathrm{LNP}_{\mathrm{CH}}-0.6247 \mathrm{LNP}_{\mathrm{HK}}-1.7542 \mathrm{LNP}_{\mathrm{JAP}}+0.4929 \mathrm{LNP}_{\mathrm{TW}}+2.9497 \mathrm{LNP}_{\mathrm{KOR}}-0.2571$ LNREXP -0.0097 Trend +4.4231
$(0.8379)$
(0.3277)
$(0.4401)$
(0.8386)
(0.6710)
$(0.0808)$
$(0.0034)$

Model 3 Japan: $W_{J A P}=f\left(\mathrm{LNP}_{\mathrm{CH}}, \mathrm{LNP}_{\mathrm{HK}}, \mathrm{LNP}_{\mathrm{JAP}}, \mathrm{LNP}_{\mathrm{TW}}, \mathrm{LNP}_{\mathrm{KOR}}, L N R E X P\right)$

\begin{tabular}{|c|c|c|c|c|c|c|}
\hline Hypothesis & $r=0$ & $c . v .1 \%$ & Prob.** & $r \leq 1$ & c.v. $1 \%$ & Prob.** \\
\hline Trace test & $167.2359^{*}$ & 150.5585 & 0.0040 & 116.7876 & 117.7082 & 0.0571 \\
\hline$\lambda$ max test & 50.4484 & 50.5999 & 0.0518 & 43.2649 & 474.4972 & 0.0677 \\
\hline \\
\hline
\end{tabular}

Model 4 Taiwan: $W_{T W}=f\left(\mathrm{LNP}_{\mathrm{CH}}, \mathrm{LNP}_{\mathrm{HK}}, \mathrm{LNP}_{\mathrm{JAP}}, \mathrm{LNP}_{\mathrm{TW}}, \mathrm{LNP}_{\mathrm{KOR}}\right.$, LNREXP $)$

\begin{tabular}{|c|c|c|c|c|c|c|}
\hline Hypothesis & $r=0$ & c.v. $5 \%$ & Prob.** & $r \leq 1$ & P.v. $5 \%$ & Prob.** \\
\hline Trace test & $172.4440^{*}$ & 125.6154 & 0.0000 & 86.3323 & 95.7537 & 0.0899 \\
\hline$\lambda$ max test & $86.1118^{*}$ & 46.2314 & 0.0000 & 35.0164 & 40.0776 & 0.1666 \\
\hline \\
ECT $=W_{T W}+0.6411 \mathrm{LNP}_{\mathrm{CH}}+0.2297 \mathrm{LNP}_{\mathrm{HK}}+0.1911 \mathrm{LNP}_{\mathrm{JAP}}-0.1161 \mathrm{LNP}_{\mathrm{TW}}-0.9968 \mathrm{LNP}_{\mathrm{KOR}}-0.0448 L N R E X P-0.1497$ \\
\\
$(0.0680)(0.0795)$ & $(0.0689)$ & $(0.1128)$ & $(0.1726)$ & $(0.0193)$ \\
\hline
\end{tabular}

Model 5 Korea: $W_{K O R}=f\left(\mathrm{LNP}_{\mathrm{CH}}, \mathrm{LNP}_{\mathrm{HK}}, \mathrm{LNP}_{\mathrm{JAP}}, \mathrm{LNP}_{\mathrm{TW}}, \mathrm{LNP}_{\mathrm{KOR}}\right.$, LNREXP $)$

\begin{tabular}{|c|c|c|c|c|c|c|}
\hline Hypothesis & $r=0$ & $c . v .5 \%$ & Prob.** & $r \leq 1$ & c.v.5\% & Prob.** \\
\hline Trace test & $131.0261 *$ & 125.6154 & 0.0225 & 87.3087 & 95.7537 & 0.1653 \\
\hline$\lambda$ max test & 43.7174 & 46.2314 & 0.0909 & 33.7889 & 40.0776 & 0.2151 \\
\hline \\
ECT $=W_{K O R}-0.1182 \mathrm{LNP}_{\mathrm{CH}}+0.2180 \mathrm{LNP}_{\mathrm{HK}}-0.1518 \mathrm{LNP}_{\mathrm{JAP}}+0.0319 \mathrm{LNP}_{\mathrm{TW}}-0.1103 \mathrm{LNP}_{\mathrm{KOR}}-0.0142 L N R E X P+0.4759$ \\
\\
$(0.0838) \quad(0.0882)$ & $(0.0752)$ & $(0.1219)$ & $(0.1893)$ & $(0.0238)$
\end{tabular}

Note: $(1) *$ denotes rejection of the null hypothesis at the 5\% level, ** MacKinnon-Haug-Michelis (1999) p-values. (2) standard error in parentheses. (3) Cointegrating vector lags were chosen on the basis of AIC, HQ and SC criteria. (4) c.v. denotes critical value. 
Table 9

Estimates of nonlinear ECM model for Thai outbound tourism demand for East Asia

\begin{tabular}{|c|c|c|c|c|c|}
\hline Variables & China & Hong Kong & Japan & Taiwan & Korea \\
\hline \multirow[t]{2}{*}{ Intercept } & 0.0024 & -0.0002 & $-0.0063 *$ & 0.0014 & 1.0027 \\
\hline & $(0.6056)$ & $(-0.0488)$ & $(-1.8131)$ & $(0.4382)$ & $(4.0525)$ \\
\hline \multirow[t]{2}{*}{$E C T_{t-1}$} & $-0.4949 * * *$ & $-0.1053 * * *$ & $-0.2469 * * *$ & $-0.6304 * * *$ & \\
\hline & $(-8.2299)$ & $(-3.5704)$ & $(-5.2995)$ & $(-8.9419)$ & \\
\hline \multirow{2}{*}{$\Delta \mathrm{LNP}_{\mathrm{CH}, \mathrm{t}-1}$} & -0.1779 & 0.1926 & 0.0322 & 0.0496 & -0.1441 \\
\hline & $(-0.6917)$ & (1.1902) & $(0.3542)$ & $(0.2746)$ & $(-1.5814)$ \\
\hline \multirow{2}{*}{$\Delta \mathrm{LNP}_{\mathrm{HK}, \mathrm{t}-1}$} & 0.1926 & -0.1989 & 0.0998 & 0.0247 & 0.0726 \\
\hline & (1.1902) & $(-0.9891)$ & (1.0877) & $(0.1162)$ & $(0.6215)$ \\
\hline \multirow{2}{*}{$\Delta \mathrm{LNP}_{\mathrm{JAP}, \mathrm{t}-1}$} & 0.0322 & 0.0998 & 0.0527 & -0.0131 & -0.0735 \\
\hline & $(0.3542)$ & (1.0877) & $(0.6047)$ & $(-0.0911)$ & $(-1.1451)$ \\
\hline \multirow{2}{*}{$\Delta \mathrm{LNP}_{\mathrm{TW}, \mathrm{t}-1}$} & 0.0496 & 0.0247 & -0.0131 & -0.2382 & 0.0869 \\
\hline & $(0.2746)$ & $(0.1162)$ & $(-0.0911)$ & $(-1.5061)$ & $(0.9117)$ \\
\hline \multirow{2}{*}{$\Delta \mathrm{LNP}_{\mathrm{KOR}, \mathrm{t}-1}$} & -0.1441 & 0.0726 & -0.0735 & 0.0869 & 0.0581 \\
\hline & $(-1.5814)$ & $(0.6215)$ & $(-1.1451)$ & (0.9117) & $(0.7458)$ \\
\hline \multirow{2}{*}{$\Delta \mathrm{LNREXP}_{\mathrm{t}-1}^{\mathrm{n}}$} & $-0.1864 * * *$ & 0.0243 & $0.0865 * * *$ & $0.0841 * *$ & -0.0085 \\
\hline & $(-4.9193)$ & $(0.5726)$ & (2.6784) & $(2.5791)$ & $(-0.3241)$ \\
\hline \multirow[t]{2}{*}{ Ds } & $-0.0792 * * *$ & -0.0188 & $0.0571 * * *$ & $0.0429 * * *$ & \\
\hline & $(-5.3946)$ & $(-1.1711)$ & (4.3168) & $(3.5155)$ & \\
\hline \multirow[t]{2}{*}{$\mathrm{Da}$} & 0.0078 & -0.0044 & $0.0092 *$ & -0.0076 & \\
\hline & (1.2546) & $(-0.6403)$ & (1.6923) & $(-1.5153)$ & \\
\hline \multirow[t]{2}{*}{$\Delta w_{i t-1}$} & -0.0896 & $-0.2563 * * *$ & $-0.1670 * * *$ & 0.0163 & \\
\hline & $(-1.6148)$ & $(-4.1614)$ & $(-2.6371)$ & $(0.2666)$ & \\
\hline $\mathrm{R}^{2}$ & 0.6904 & 0.6433 & 0.5163 & 0.6786 & \\
\hline Adjusted $\mathrm{R}^{2}$ & 0.6227 & 0.5652 & 0.4105 & 0.6082 & \\
\hline DW & 2.1915 & 2.1229 & 1.7775 & 2.1897 & \\
\hline
\end{tabular}

Notes: 1. Monthly dummies are controlled in the regressions.

2. $\mathrm{t}$-statistics are reported in parentheses. $* * *, * *$ and $*$ indicate significance at the $1 \%, 5 \%$ and $10 \%$ levels, respectively. 


\section{Table 10}

Estimates of linear ECM model for Thai outbound tourism demand for East Asia

\begin{tabular}{|c|c|c|c|c|c|}
\hline Variables & China & Hong Kong & Japan & Taiwan & Korea \\
\hline \multirow[t]{2}{*}{ Intercept } & 0.0015 & 0.00034 & $-0.0066^{*}$ & 0.0023 & $1.0025 * * *$ \\
\hline & $(0.3768)$ & (0.0769) & $(-1.9554)$ & $(0.7543)$ & (4.041) \\
\hline \multirow[t]{2}{*}{$E C T_{t-1}$} & $-0.4855^{* * * *}$ & $-0.1273 * * *$ & $-0.2582 * * *$ & $-0.6158 * * *$ & \\
\hline & $(-8.1107)$ & $(-4.5449)$ & $(-5.5841)$ & $(-9.1077)$ & \\
\hline \multirow{2}{*}{$\Delta \mathrm{LNP}_{\mathrm{CH}, \mathrm{t}-1}$} & 0.0729 & 0.0452 & -0.0049 & $-0.2994 *$ & $0.3052 * * *$ \\
\hline & $(0.2100)$ & $(0.1426)$ & $(-0.0535)$ & $(-1.7588)$ & $(3.1531)$ \\
\hline \multirow{2}{*}{$\Delta \mathrm{LNP}_{\mathrm{HK}, \mathrm{t}-1}$} & 0.0452 & -0.5063 & 0.0110 & $0.5799 * * *$ & -0.0899 \\
\hline & $(0.1426)$ & $(-1.4399)$ & $(0.1121)$ & $(3.4988)$ & $(-0.8509)$ \\
\hline \multirow{2}{*}{$\Delta \mathrm{LNP}_{\mathrm{JAP}, \mathrm{t}-1}$} & -0.0049 & 0.0110 & 0.0828 & 0.0039 & $-0.2593 * * *$ \\
\hline & $(-0.0536)$ & $(0.1122)$ & $(1.0305)$ & $(0.0548)$ & $(-3.3709)$ \\
\hline \multirow[t]{2}{*}{$\Delta \mathrm{LNP}_{\mathrm{TW}, \mathrm{t}-1}$} & $-0.2994 *$ & $0.5799 * * *$ & 0.0039 & -0.2451 & -0.0639 \\
\hline & $(-1.7588)$ & $(3.4989)$ & $(0.0547)$ & $(-1.5158)$ & $(-0.8428)$ \\
\hline \multirow{2}{*}{$\Delta \mathrm{LNP}_{\mathrm{KOR}, \mathrm{t}-1}$} & $0.3052 * * *$ & -0.0899 & $-0.2593 * * *$ & -0.0639 & $0.1079 *$ \\
\hline & $(3.1531)$ & $(-0.8509)$ & $(-3.3709)$ & $(-0.8428)$ & $(1.7150)$ \\
\hline \multirow[t]{2}{*}{$\Delta \mathrm{LNREXP}_{\mathrm{t}-1}$} & $-0.0629 * *$ & -0.0307 & $0.0468 * *$ & $0.0745 * * *$ & -0.0277 \\
\hline & $(-2.0988)$ & $(-0.9658)$ & $(1.8626)$ & (3.1957) & $(-1.3895)$ \\
\hline \multirow[t]{2}{*}{ Ds } & $-0.0634 * * *$ & -0.0247 & $0.0505 * * *$ & $0.0399 * * *$ & \\
\hline & $(-4.3823)$ & $(-1.5472)$ & (3.9519) & (3.4879) & \\
\hline \multirow[t]{2}{*}{$\mathrm{Da}$} & 0.0065 & -0.0046 & $0.0099 *$ & -0.0074 & \\
\hline & (1.0342) & $(-0.6678)$ & $(1.8465)$ & $(-1.5096)$ & \\
\hline \multirow[t]{2}{*}{$\Delta w_{i t-1}$} & -0.0264 & $-0.1869 * * *$ & $-0.1167 *$ & 0.0621 & \\
\hline & $(-0.4306)$ & $(-3.0079)$ & $(-1.8012)$ & (1.0084) & \\
\hline $\mathrm{R}^{2}$ & 0.6861 & 0.6378 & 0.5283 & 0.6996 & \\
\hline Adjusted $\mathrm{R}^{2}$ & 0.6174 & 0.5586 & 0.4251 & 0.6339 & \\
\hline DW & 2.0095 & 2.2097 & 1.7326 & 2.1969 & \\
\hline
\end{tabular}

Notes: 1. Monthly dummies are controlled in the regressions.

2. t-statistics are reported in parentheses. $* * *, * *$ and $*$ indicate significance at the $1 \%, 5 \%$ and $10 \%$ levels, respectively. 
Figure 1: Thai Outbound Tourism by Continent, 1998-2007

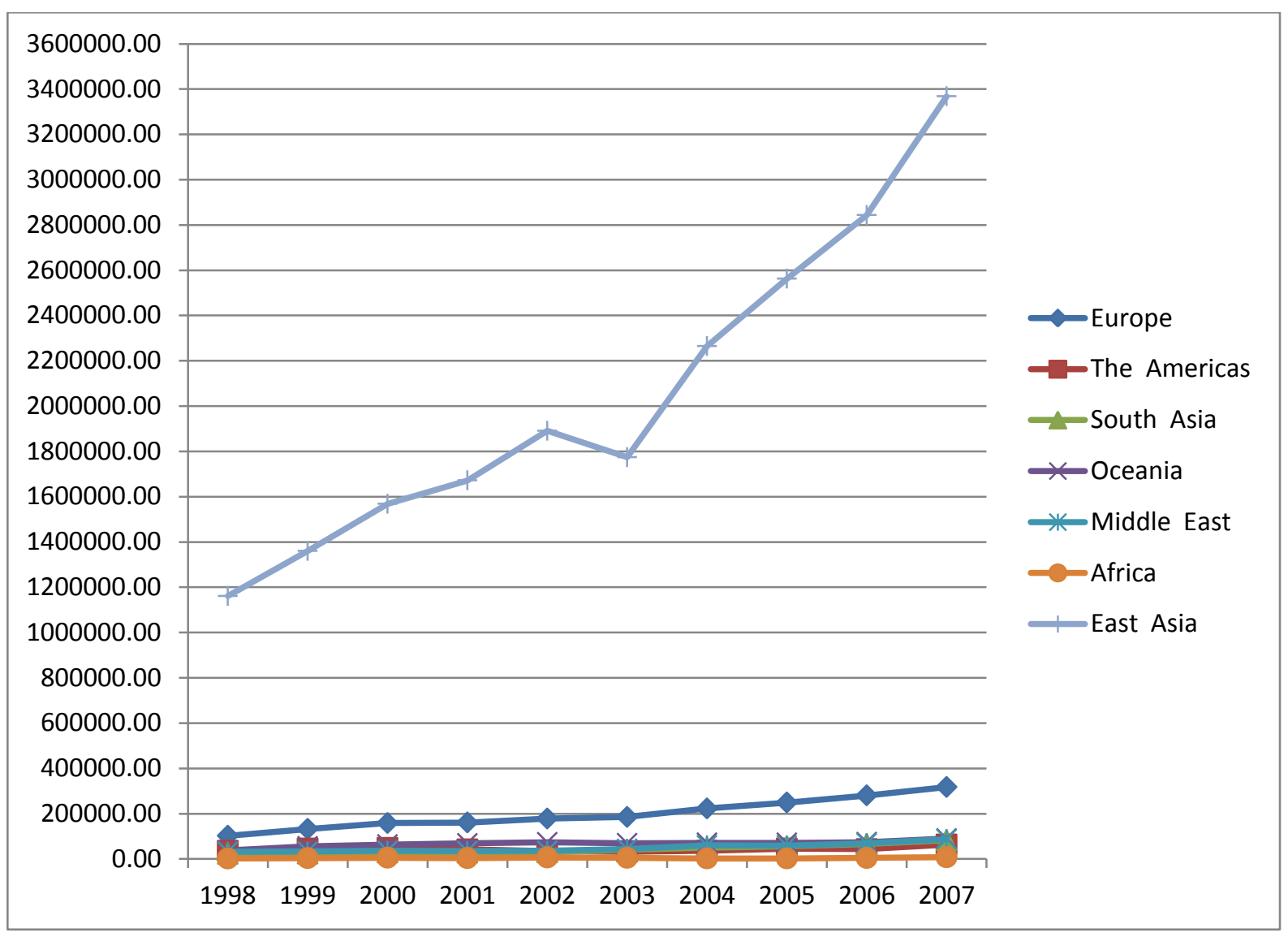

Source: Annual Statistical Report on Tourism in Thailand 1998-2007, Tourism Authority of Thailand (1998-2007). 
Figure 2: Residuals from long run budget share equations

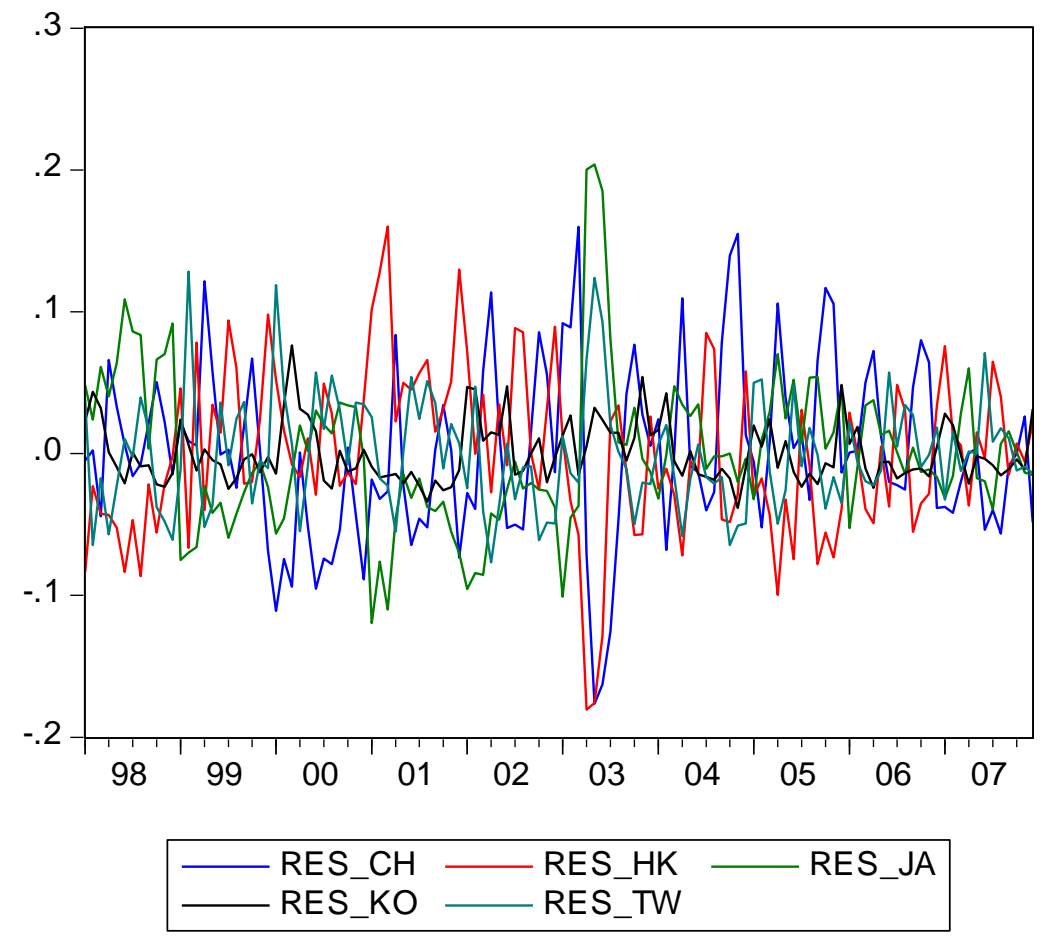

